\title{
Variability of carbon monoxide and carbon dioxide apparent quantum yield spectra in three coastal estuaries of the South Atlantic Bight
}

\author{
H. E. Reader ${ }^{1, *}$ and W. L. Miller ${ }^{1}$ \\ ${ }^{1}$ Marine Sciences Department, University of Georgia, Athens, Georgia 30602, USA \\ * current address: Aquatic Ecology Unit, Department of Biology, Lund University, Sölvegatan 37, 223 62 Lund, Sweden
}

Correspondence to: W. L. Miller (bmiller@uga.edu)

Received: 7 May 2012 - Published in Biogeosciences Discuss.: 14 June 2012

Revised: 10 October 2012 - Accepted: 11 October 2012 - Published: 6 November 2012

\begin{abstract}
The photochemical oxidation of oceanic dissolved organic carbon (DOC) to carbon monoxide (CO) and carbon dioxide $\left(\mathrm{CO}_{2}\right)$ has been estimated to be a significant process with global photoproduction transforming petagrams of DOC to inorganic carbon annually. To further quantify the importance of these two photoproducts in coastal DOC cycling, 38 paired apparent quantum yield (AQY) spectra for $\mathrm{CO}$ and $\mathrm{CO}_{2}$ were determined at three locations along the coast of Georgia, USA over the course of one year. The AQY spectra for $\mathrm{CO}_{2}$ were considerably more varied than $\mathrm{CO}$. CO AQY spectra exhibited a seasonal shift in spectrally integrated $(260 \mathrm{~nm}-490 \mathrm{~nm})$ AQY from higher efficiencies in the autumn to less efficient photoproduction in the summer. While full-spectrum photoproduction rates for both products showed positive correlation with pre-irradiation UV-B sample absorption (i.e. chromophoric dissolved organic matter, CDOM) as expected, we found no correlation between AQY and CDOM for either product at any site. Molecular size, approximated with pre-irradiation spectral slope coefficients, and aromatic content, approximated by the specific ultraviolet absorption of the pre-irradiated samples, were also not correlated with AQY in either data set. The ratios of $\mathrm{CO}_{2}$ to $\mathrm{CO}$ photoproduction determined using both an AQY model and direct production comparisons were $23.2 \pm 12.5$ and $22.5 \pm 9.0$, respectively. Combined, both products represent a loss of 2.9 to $3.2 \%$ of the DOC delivered to the estuaries and inner shelf of the South Atlantic Bight yearly, and 6.4 to $7.3 \%$ of the total annual degassing of $\mathrm{CO}_{2}$ to the atmosphere. This result suggests that direct photochemical production of $\mathrm{CO}$ and $\mathrm{CO}_{2}$ is a small, yet significant contributor
\end{abstract}

to both DOC cycling and $\mathrm{CO}_{2}$ gas exchange in this coastal system.

\section{Introduction}

The ocean represents one of the largest and most dynamic reservoirs for reduced carbon on Earth with a pool of dissolved organic carbon (DOC) on the order of $600 \mathrm{Pg} / \mathrm{C}$ (Hansell et al., 2009; Canadell et al., 2007). Coastal systems are a dynamic subset of this DOC pool with carbon inputs from terrestrial sources adding to in-situ production. Rivers contribute up to $0.2 \mathrm{Pg} / \mathrm{C}$ DOC to coastal systems per year with most having had little exposure to sunlight before its arrival in coastal waters (Ludwig et al., 1996). Carbon of terrestrial origin is generally refractory to microbial oxidation and strongly absorbs solar radiation in blue and ultraviolet (UV) wavelengths (Bricaud et al., 1981; Carlson, 2002). Regardless of source, the optically active fraction of DOC is referred to as chromophoric dissolved organic matter (CDOM) and absorbs much of the energetic UV radiation entering the water column. This both shields the marine biological community from damage and captures the energy required to initiate most photochemical reactions in the surface ocean.

Despite the continuous input of CDOM to the coastal ocean via continental sources, ocean water as a whole is not highly coloured, due largely to photochemical transformations that are known to alter the absorptive characteristics of coloured components within the DOC pool (Andrews et al., 2000; Del Vecchio and Blough, 2002; Goldstone et al., 
2004; Osburn et al., 2009). The absorption of solar radiation by CDOM can lead to a whole host of chemical reactions, including formation of reactive oxygen species such as hydroxyl radical $(\mathrm{OH} \bullet)$ and superoxide $\left(\mathrm{O}_{2}^{-}\right)$(Micinski et al., 1993; Moffett and Zafiriou, 1993; Zika et al., 1985; Blough and Zepp, 1995), breakdown of large organic molecules into lower molecular weight carbon compounds (Wetzel et al., 1995; Kieber et al., 1989, 1990), alteration of the redox state of biologically important metals (White et al., 2003; Barbeau, 2006; Barbeau et al., 2003), and formation of oxidized inorganic carbon species, such as $\mathrm{CO}$ and $\mathrm{CO}_{2}$ (measured as DIC) (Clark et al., 2004; Johannessen and Miller, 2001; Miller and Zepp, 1995; White et al., 2010; Ziolkowski and Miller, 2007; Wang et al., 2009; Xie et al., 2004; Zafiriou et al., 2003). On an annual global basis, photoproduction of these two carbon compounds may be almost equal to oceanic new production $\left(\sim 10^{15}\right.$ moles $\mathrm{C} \mathrm{yr}^{-1}$; Johannessen, 2000; Wang et al., 2009).

Photochemical production is the major source of $\mathrm{CO}$ in the surface ocean and, as a relatively insoluble gas, it can be transferred to the lower atmosphere where it competes with methane as a major sink for hydroxyl radical, thus indirectly contributing to changes in greenhouse gas concentrations (Shindell et al., 2009). CO in seawater can also be used as a substrate for marine bacteria (Tolli et al., 2006; Kitidis et al., 2011), efficiently competing with gas exchange to lessen its transfer to the atmosphere. Even with these two removal pathways, $\mathrm{CO}$ is supersaturated with respect to the atmosphere in the surface ocean, having concentrations from $\sim 2 \mathrm{nM}$ in the open ocean to $\sim 12 \mathrm{nM}$ in the coastal ocean (Zafiriou et al., 2008, 2003). As is the case with other photoproducts, oceanic $\mathrm{CO}$ concentrations show a distinct diurnal signal with a late afternoon peak. This may reflect the photoinhibition of $\mathrm{CO}$ uptake by bacteria, with higher bacterial consumption rates when solar UV radiation is less intense and substrate concentrations have been elevated by photochemistry (Tolli and Taylor, 2005). Photochemical production of CO in the oceans has been well studied recently (Day and Faloona, 2009; Miller and Moran, 1997; Stubbins et al., 2008, 2006; White et al., 2010; Xie et al., 2009; Zafiriou et al., 2003, 2008; Ziolkowski and Miller, 2007; Kitidis et al., 2011), and global annual production of $\mathrm{CO}$ in the worlds oceans is currently estimated at between 30 and $84 \mathrm{Tg} \mathrm{C} \mathrm{yr}^{-1}$ (Zafiriou et al., 2003; Stubbins et al., 2006; Fichot and Miller, 2010).

Increased $\mathrm{CO}_{2}$ concentrations in the surface ocean from rising atmospheric $\mathrm{CO}_{2}$ levels are creating a more acidic ocean, raising concerns for the health of calcareous organisms critical to carbonate balance in the oceans (Moy et al., 2009; Fabry et al., 2008). Overall, the ocean is a sink for atmospheric $\mathrm{CO}_{2}$; however, some coastal systems, such as the terrestrially influenced South Atlantic Bight (USA) and the Pearl River estuary (China), have been reported as seasonal sources of $\mathrm{CO}_{2}$ to the atmosphere (Guo et al., 2009; Jiang et al., 2008b; Wang et al., 2005), with the inner shelf and estuaries being the strongest sources (Cai, 2011; Jiang et al., 2008a) presumably due to heterotrophic production in these regions. Photochemical production of dissolved inorganic carbon (DIC) in the form of $\mathrm{CO}_{2}$ from the oxidation of DOC has the potential to add to the source strength in these areas with high organic carbon content.

The photochemical production of $\mathrm{CO}_{2}$ (generally measured as total DIC but discussed as $\mathrm{CO}_{2}$ ) has been studied in both freshwater (Anesio and Graneli, 2004, 2003; Bertilsson and Tranvik, 2000; Graneli et al., 1998; Salonen and Vahatalo, 1994) and marine systems (Belanger et al., 2006; Gao and Zepp, 1998; Johannessen and Miller, 2001; Miller and Zepp, 1995), though the extent of coverage in marine systems is considerably less. Several noteworthy studies have pointed towards a strong global photochemical signal of DIC production in the ocean (White et al., 2010; Johannessen and Miller, 2001; Miller and Zepp, 1995).

The analytical constraints on measuring the photochemical production of $\mathrm{CO}_{2}$ in seawater containing an inorganic carbon pool over $100 \times$ more concentrated than changes created by photochemical production are significant. Consequently, there has been some focus on establishing a valid ratio relating $\mathrm{CO}_{2}$ and $\mathrm{CO}$ photoproduction that would allow use of the more prevalent $\mathrm{CO}$ data to assess the magnitude of photochemical $\mathrm{CO}_{2}$ production in the oceans. Early estimates of the $\mathrm{CO}_{2}$ : $\mathrm{CO}$ photochemical production ratio were 15-20 (Miller and Zepp, 1995; Mopper and Kieber, 2000), but more recent studies have shown that this ratio is much more variable, ranging from $\sim 2$ to 98 in some cases (White et al., 2010). This ratio may be dependent on the source material comprising the CDOM. Photochemical efficiencies for both $\mathrm{CO}$ and $\mathrm{CO}_{2}$ (i.e. apparent quantum yield spectra, $\mathrm{AQY}$ ) have been reported to vary depending on carbon source ( $\mathrm{Zi}$ olkowski and Miller, 2007; Johannessen and Miller, 2001) with $\mathrm{CO} A Q Y$ spectra appearing to be more constant than those for $\mathrm{CO}_{2}$.

Together, $\mathrm{CO}$ and $\mathrm{CO}_{2}$ constitute the largest analytically identifiable carbon photoproducts in the ocean and, as such, have potential to affect the cycling of DOC in the oceans. The following study provides new data that will better constrain the natural variability of $\mathrm{CO}$ and $\mathrm{CO}_{2}$ photoproduction and its significance to DOC cycling in the coastal ocean. Thirty-eight (38) samples were collected from three sites along the coast of Georgia, USA, over the course of a year for paired determinations of $\mathrm{CO}$ and $\mathrm{CO}_{2} \mathrm{AQY}$ spectra together with measurements of potential environmental parameters that may provide insight into these photochemical processes. The results presented here provide the most extensive set of paired $\mathrm{CO}$ and $\mathrm{CO}_{2} \mathrm{AQY}$ and photoproduction data collected to date, allowing a robust consideration of their relative production rates and photochemical efficiency. 


\section{Methods}

\subsection{Sample collection}

Samples were collected for both $\mathrm{CO}$ and $\mathrm{CO}_{2}$ photochemical experiments, monthly during spring high tide and quarterly during spring low tide. Three sites were chosen within the Georgia Coastal Ecosystems Long Term Ecological Research (GCE LTER) area, meant to represent three variants of coastal estuarine systems (Fig. 1). Sapelo Sound $\left(31.537779^{\circ} \mathrm{N}, 81.176860^{\circ} \mathrm{W}\right)$ is a coastal marine dominated site, with little freshwater input over the year. Altamaha Sound $\left(31.314000^{\circ} \mathrm{N}, 81.265333^{\circ} \mathrm{W}\right)$ receives outflow from the Altamaha River, which drains the largest watershed in the state of Georgia, and is a mixed riverine and marsh site. Doboy Sound $\left(31.376373^{\circ} \mathrm{N}, 81.281718^{\circ} \mathrm{W}\right)$ is primarily a coastal marine dominated site but receives significant freshwater input from the Altamaha River during periods of high flow. Samples were collected in concert with the GCE LTER monthly mini-cruise program. Sample characteristics can be found in Table 1. Samples were collected in acid-washed polycarbonate bottles (Nalgene, 21 ) and stored on ice until returned to the laboratory $(<3 \mathrm{~h})$. Samples were then immediately filtered using an acid-cleaned $0.2 \mu \mathrm{m}$ nylon cartridge filter (Whatman Polycap AS 75) and were then stored in the dark at $4{ }^{\circ} \mathrm{C}$ until the photochemical evaluation $(0$ 6 months). Previous evaluations in our lab (unpublished) and work such as Stedmon and Markager (2001) and Swan et al. (2012) have shown that storage had little effect on CDOM absorption, and thus storage was determined not to be an issue.

\subsection{Sample and labware preparation}

To analyze the photoproduction of DIC (i.e. $\mathrm{CO}_{2}$ ) in micromolar amounts in seawater, the ambient DIC in all samples (i.e. $\mathrm{CO}_{2}, \mathrm{HCO}_{3}^{-}, \mathrm{CO}_{3}^{2-}$ ) was removed from the sample prior to irradiation following the methods of Johannessen and Miller (2001). Briefly, 11 of sample was transferred to a UV-C sterilized glass kettle, acidified to $\mathrm{pH} 2-3$ using a nominal amount of concentrated $\mathrm{HCl}$ to minimize dilution (Fisher Scientific), and bubbled overnight $(\sim 8 \mathrm{~h})$ under positive pressure with $\mathrm{CO}_{2}$-free (soda lime column, $12^{\prime \prime} \times 1.5^{\prime \prime}$, Fisher Scientific, indicating grade) room air to ensure complete removal of DIC from the solution. Successful treatment was confirmed via direct analysis using a Shimadzu TOC VCPN in IC mode (see Sect. 2.3).

Quartz spectrophotometric cells (Spectrocell Inc, $10 \mathrm{~cm}$ pathlength) for use in DIC photochemical experiments were sterilized with a UV-C lamp at close range (less than $30 \mathrm{~cm}$ ) for an hour before filling to ensure that $\mathrm{CO}_{2}$ produced during the course of an irradiation was due to photochemical production rather than biological respiration. Once DIC was removed from a sample, it was rebuffered to its initial $\mathrm{pH}(\sim 7-$ $8 \mathrm{pH}$ ) using crystalline sodium borate (Fisher Scientific, ACS

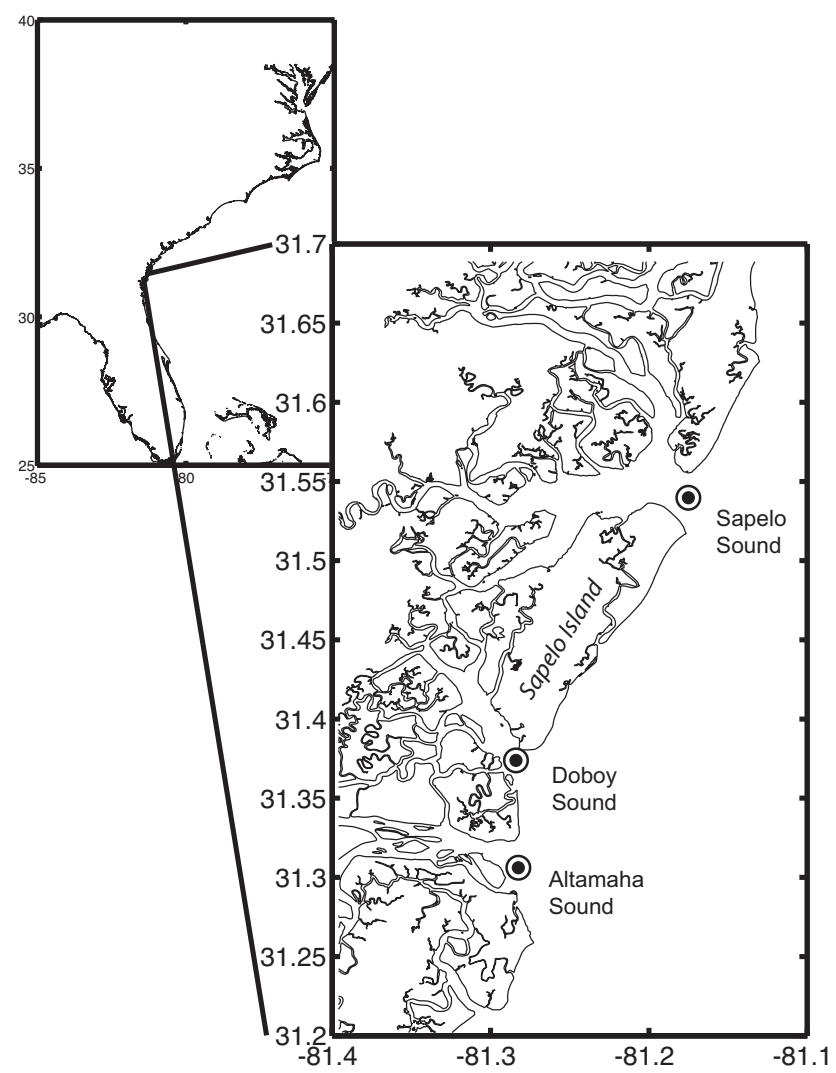

Fig. 1. Sample sites for the seasonal study.

grade). Immediately after raising the $\mathrm{pH}$, the spectrophotometric cells were filled using a gas-tight glass dispenser while keeping the sample under positive pressure with $\mathrm{CO}_{2}-$ free air. Cells were then sealed headspace-free, using $13 \mathrm{~mm}$ diameter, 1-mm-thick Teflon-faced butyl rubber septa, placed in a chilled aluminum block (held at $15{ }^{\circ} \mathrm{C}$ ), and mounted within a Suntest solar simulator (Suntest CPS) for radiation exposure.

Samples for measurement of $\mathrm{CO}$ photochemical production did not require the removal of DIC and were not subject to contamination from microbial respiration. Consequently, these were simply filtered a second time $(0.2 \mu \mathrm{m}$ Whatman Polycap AS75) just prior to placing them directly into acid-washed and oven-dried spectrophotometric cells, sealed without a headspace, and exposed in the solar simulator in the same manner as was done in the $\mathrm{CO}_{2}$ experiments.

\subsection{Photochemical irradiations}

Photochemical irradiations were performed following the multispectral methods of Johannessen and Miller (2001). A tightly fitted $2.4-\mathrm{cm}$-thick black plastic lid with $1.6 \mathrm{~cm}$ diameter holes drilled directly above over each spectrophotometric cell served as effective Gershun tubes for each cell to minimize off-axis light, thus minimizing reflection at the air-quartz surface of the cells. To create distinct irradiation 
Table 1. Sample characteristics and AQY fitting parameters for all samples.

\begin{tabular}{|c|c|c|c|c|c|c|c|c|c|c|c|}
\hline \multirow[b]{2}{*}{ Date } & \multirow[b]{2}{*}{ Site } & \multirow[b]{2}{*}{ Tide } & \multirow[b]{2}{*}{ Salinity } & \multirow[b]{2}{*}{ DOC $\left(\mu \mathrm{mol} 1^{-1}\right)$} & \multirow[b]{2}{*}{$\operatorname{ag} 320\left(\mathrm{~m}^{-1}\right)$} & \multicolumn{3}{|c|}{$\mathrm{CO}$} & \multicolumn{3}{|c|}{$\mathrm{CO}_{2}$} \\
\hline & & & & & & $\mathrm{m} 1$ & $\mathrm{~m} 2$ & $\mathrm{~m} 3$ & $\mathrm{~m} 1$ & $\mathrm{~m} 2$ & $\mathrm{~m} 3$ \\
\hline $11 / 11 / 08$ & ALT & HT & 32.2 & 226 & 4.101 & 7.996 & 0.039 & 274.610 & 6.115 & 0.016 & 280.715 \\
\hline $11 / 11 / 08$ & ALT & $\mathrm{LT}$ & 22.1 & 432 & 13.775 & 8.310 & 0.026 & 264.170 & 5.758 & 0.033 & 295.546 \\
\hline $11 / 12 / 08$ & SAP & HT & 33.2 & 287 & 3.263 & 7.700 & 0.060 & 281.660 & 5.750 & 0.037 & 296.051 \\
\hline $11 / 12 / 08$ & SAP & $\mathrm{LT}$ & 32.6 & 275 & 6.155 & 8.012 & 0.037 & 273.820 & 5.986 & 0.032 & 290.303 \\
\hline $11 / 13 / 08$ & DOB & HT & 33 & 213 & 4.113 & 7.933 & 0.038 & 275.060 & n.d. & n.d. & n.d. \\
\hline $11 / 13 / 08$ & DOB & LT & 30.8 & 335 & 7.438 & 8.156 & 0.032 & 269.210 & 5.731 & 0.065 & 296.035 \\
\hline $12 / 10 / 08$ & DOB & HT & n.d. & n.d. & 6.593 & n.d. & n.d. & n.d. & 5.730 & 0.034 & 296.543 \\
\hline $2 / 16 / 09$ & ALT & HT & 30.2 & 226 & 5.453 & 8.147 & 0.031 & 269.340 & 5.563 & 0.068 & 300.934 \\
\hline $2 / 17 / 09$ & SAP & HT & 31.8 & 216 & 4.557 & 7.974 & 0.039 & 274.610 & 5.699 & 0.046 & 297.929 \\
\hline $2 / 18 / 09$ & DOB & HT & 29.4 & 235 & 5.720 & 7.973 & 0.037 & 274.020 & 5.738 & 0.072 & 295.630 \\
\hline $3 / 11 / 09$ & ALT & HT & 31.1 & 208 & 5.058 & 8.148 & 0.028 & 268.480 & 5.901 & 0.024 & 290.118 \\
\hline $3 / 11 / 09$ & ALT & $\mathrm{LT}$ & 4.7 & 678 & 23.558 & 8.516 & 0.020 & 251.380 & 6.078 & 0.027 & 286.684 \\
\hline $3 / 12 / 09$ & SAP & HT & 31.7 & 213 & 4.716 & 8.120 & 0.036 & 271.770 & 5.924 & 0.030 & 292.303 \\
\hline $3 / 12 / 09$ & SAP & $\mathrm{LT}$ & 31.1 & 247 & 5.378 & 8.034 & 0.037 & 273.430 & 5.913 & 0.041 & 292.188 \\
\hline $3 / 13 / 09$ & DOB & HT & 29.8 & 227 & 5.649 & 8.135 & 0.028 & 268.460 & 5.672 & 0.033 & 297.253 \\
\hline $3 / 13 / 09$ & DOB & $\mathrm{LT}$ & 23.2 & 349 & 9.711 & 8.361 & 0.026 & 263.240 & 5.996 & 0.028 & 290.585 \\
\hline $4 / 14 / 09$ & SAP & HT & 26.7 & 293 & 8.038 & 8.353 & 0.026 & 262.010 & 5.990 & 0.028 & 289.501 \\
\hline $5 / 11 / 09$ & ALT & HT & 1.5 & 269 & 7.801 & 8.407 & 0.025 & 260.890 & 5.490 & 0.054 & 302.849 \\
\hline $5 / 11 / 09$ & ALT & $\mathrm{LT}$ & 7.3 & 621 & 24.105 & 8.379 & 0.026 & 262.420 & 5.572 & 0.044 & 300.501 \\
\hline $5 / 12 / 09$ & SAP & HT & 30.2 & 322 & 9.136 & 8.161 & 0.034 & 270.270 & 5.786 & 0.042 & 295.370 \\
\hline $5 / 12 / 09$ & SAP & $\mathrm{LT}$ & 28.5 & 390 & 12.187 & 8.179 & 0.033 & 269.490 & 5.725 & 0.071 & 295.866 \\
\hline $5 / 13 / 09$ & DOB & HT & 30.8 & 283 & 8.286 & 8.241 & 0.030 & 266.970 & 5.896 & 0.044 & 292.614 \\
\hline $5 / 13 / 09$ & DOB & $\mathrm{LT}$ & 24.6 & 461 & 15.559 & 8.310 & 0.029 & 265.770 & 6.094 & 0.018 & 280.470 \\
\hline $6 / 15 / 09$ & ALT & HT & 28.1 & 522 & 22.697 & 8.453 & 0.028 & 262.570 & 6.115 & 0.030 & 286.801 \\
\hline $6 / 16 / 09$ & SAP & HT & 31.9 & 252 & 6.660 & 8.004 & 0.044 & 275.800 & 5.899 & 0.043 & 292.532 \\
\hline $6 / 17 / 09$ & DOB & HT & 31.2 & 271 & 7.718 & 8.147 & 0.038 & 272.050 & n.d. & n.d. & n.d. \\
\hline 7/13/09 & ALT & HT & 31.7 & 230 & 6.819 & 8.013 & 0.045 & 275.810 & 5.717 & 0.036 & 296.717 \\
\hline $7 / 14 / 09$ & SAP & HT & 31.9 & 270 & 6.767 & 8.136 & 0.039 & 272.670 & 5.939 & 0.034 & 291.440 \\
\hline $7 / 15 / 09$ & DOB & HT & 31.1 & 232 & 6.854 & 8.054 & 0.043 & 274.910 & n.d. & n.d. & n.d. \\
\hline $8 / 11 / 09$ & ALT & HT & 33.1 & 194 & 5.109 & 7.964 & 0.049 & 277.320 & 6.281 & 0.019 & 277.841 \\
\hline $8 / 11 / 09$ & ALT & $\mathrm{LT}$ & 20.2 & 406 & 14.249 & 8.205 & 0.034 & 269.420 & 5.441 & 0.054 & 304.371 \\
\hline $8 / 12 / 09$ & SAP & HT & 34 & 211 & 5.058 & 8.070 & 0.044 & 275.070 & 5.950 & 0.029 & 291.736 \\
\hline $8 / 12 / 09$ & SAP & $\mathrm{LT}$ & 31.4 & 275 & 9.019 & 8.140 & 0.039 & 272.680 & 6.019 & 0.030 & 290.455 \\
\hline $8 / 13 / 09$ & DOB & HT & 32.5 & 165 & 4.949 & 8.054 & 0.042 & 274.670 & 5.329 & 0.086 & 307.692 \\
\hline $8 / 13 / 09$ & DOB & $\mathrm{LT}$ & 30.8 & 241 & 7.907 & 8.164 & 0.035 & 270.760 & 5.781 & 0.041 & 295.486 \\
\hline $9 / 14 / 09$ & ALT & HT & 32.5 & 207 & 4.854 & 8.336 & 0.025 & 264.250 & 6.130 & 0.019 & 282.065 \\
\hline $9 / 15 / 09$ & SAP & HT & 33.1 & 206 & 4.880 & 8.298 & 0.031 & 268.820 & 6.257 & 0.017 & 277.994 \\
\hline $9 / 16 / 09$ & DOB & HT & 31.8 & 245 & 7.297 & 8.306 & 0.029 & 269.270 & 5.737 & 0.032 & 291.713 \\
\hline
\end{tabular}

conditions for the samples in each of 14 spectrophotometric cells, duplicate Schott-glass long-pass cutoff filters (WG280, WG295, WG305, WG320, GG385, GG420, GG475) were placed directly over the lid, between the quartz cells and the light source. An opaque disk was used above the 15 th cell in the chilled Al block to provide a dark control. The spectral irradiance under the lid and under each filter was measured at $1 \mathrm{~nm}$ resolution using a 2 -inch integrating sphere attached by a $60 \mathrm{~cm}$ fiber optical cable to an Optronic model 756 spectroradiometer that was calibrated using a NIST-certified tungsten halogen standard lamp powered by an Optronic model OL752-10 power supply. Exposures lasted either 4 or $6 \mathrm{~h}$ for $\mathrm{CO}_{2}$ experiments and $3 \mathrm{~h}$ for $\mathrm{CO}$ experiments. This delivered a total photon dose under the $305 \mathrm{~nm}$ (WG305) cutoff filter that most closely simulates the solar spectrum in our system, of $0.93,1.23$, and 1.85 millimoles photons $\mathrm{cm}^{-2}$ for 3,4 , and $6 \mathrm{~h}$ respectively. The UV-visible absorbance of each sample was measured directly in the spectrophotometric exposure cells on a Perkin-Elmer Lambda-40 spectrophotometer before and after each irradiation. The absorbance spectrum was converted to absorption for use in apparent quantum yield calculations using the equation

$a(\lambda)=\frac{A(\lambda) \cdot 2.303}{\ell}$ 
where $a$ is the Napierian absorption coefficient $\left(\mathrm{m}^{-1}\right), A$ is the absorbance measured by the spectrophotometer and is unitless, $\ell$ is the pathlength of the spectrophotometric cell (m), and 2.303 converts from $\log 10$ scale to natural $\log$ scale (i.e. Napierian). In all experiments, photochemical fading was less than $1 \%$ at all wavelengths. This small change in $a(\lambda)$ was accounted for in AQY calculations by assuming linear fading and using the average at each wavelength between the starting and ending absorption spectra.

Photochemically produced $\mathrm{CO}_{2}$ was measured with a Shimadzu TOC V-CPN analyzer configured for IC analysis. It should be noted here that, like almost all studies of $\mathrm{CO}_{2}$ photochemical production in natural waters, this method quantifies $\mathrm{CO}_{2}$ as dissolved inorganic carbon (DIC) and that discussion of $\mathrm{CO}_{2}$ production in any measured sample assumes that changes in DIC are from $\mathrm{CO}_{2}$. The TOC analyzer was calibrated daily using a freshly prepared $\mathrm{Na}_{2} \mathrm{CO}_{3}$ primary standard $\left(\mathrm{Na}_{2} \mathrm{CO}_{3}\right.$, ACS Grade, Fisher Scientific), and the limit of detection was $0.014 \mu \mathrm{M}$. Following exposure, solution were drawn from the bottom of each vertically oriented, sealed spectrophotometric cell directly into a gas-tight syringe while venting room air into the top through the septa with a needle, thus minimizing the possibility for gas exchange prior to analysis. Post-irradiation spectrophotometric cells were stored under water (Millipore Milli-Q Gradient System) prior to analysis to further prevent $\mathrm{CO}_{2}$ transfer across the septa.

Photochemically produced $\mathrm{CO}$ in each sample was measured by head-space equilibration (Xie et al., 2002) on a SRI 8610C gas chromatograph fitted with a reduced gas analyzer, using a mercuric oxide ( $\mathrm{HgO}$, Fisher Scientific) reactor bed and photometric detection of the resulting mercury gas. The gas chromatograph was equipped with a 30 -cm-long $5 \AA$ molecular sieve column (SRI), and was operated at $20 \mathrm{psi}$, producing a flow rate of the $\mathrm{N}_{2}$ carrier gas of $\sim 11 \mathrm{ml} \mathrm{min}^{-1}$. To provide an initial CO-free headspace for equilibration, $13 \mathrm{ml}$ of room air was drawn slowly through a $50 \mathrm{cc}$ column of Schuetze reagent (Fisher Scientific) into the spectrophotometric cells. The exact volume of each cell varied slightly (all $\sim 30 \mathrm{ml}$ ), and thus the sample volume to headspace ratio varied around 2.3 and this was accounted for in the calculations by using the exact total volume for each cell.

The gas chromatograph was calibrated daily using a $1 \mathrm{ppm}$ CO primary standard (Scott Specialty Gas, Air Liquide) and a successive dilution with CO-free air (limit of quantification $7.8 \mathrm{ppb}$ ). In all experiments, a blank of $\mathrm{CO}$-free air drawn through the Schuetze reagent column contained undetectable levels of $\mathrm{CO}$.

\subsection{Determination of apparent quantum yield spectra}

In natural waters, the efficiency of photochemical production for $\mathrm{CO}$ and $\mathrm{CO}_{2}$ can be defined by their respective apparent quantum yield (AQY) spectra:
$\operatorname{AQY}(\lambda)=\frac{\text { mol product formed }(\lambda)}{\text { mol photons absorbed by } \operatorname{CDOM}(\lambda)}$.

The AQY is expressed as a unitless ratio and all quantities are spectral. Thus, in order to describe the efficiency of these photoreactions, both the amount of product formed and the total amount of photons absorbed by the CDOM in the sample over the course of the experiment must be known. Products are measured by the analytical techniques described above, and the number of photons absorbed over the course of an experiment for all samples is calculated using the following equation from $\mathrm{Hu}$ et al. (2002):

$Q_{\mathrm{a}}(\lambda)=E_{0}(\lambda) \times\left(a_{\mathrm{g}(\lambda)} / a_{\mathrm{t}(\lambda)}\right) \times S \times\left[1-\exp \left(-a_{\mathrm{t}(\lambda)} \times \ell\right)\right]$,

where $Q_{\mathrm{a}}$ is the moles of photons absorbed/second by the sample, $E_{0}(\lambda)$ is the scalar irradiance entering the top of the cell (mols photons $\mathrm{m}^{-2} \mathrm{~s}^{-1}$ ), $S$ is the irradiated surface area of the spectrophotometric cell $\left(\mathrm{m}^{2}\right), a_{\mathrm{g}}$ and $a_{\mathrm{t}}$ are the absorption coefficients for CDOM and for the total solution, respectively $\left(\mathrm{m}^{-1}\right)$, and $\ell$ is the pathlength of the spectrophotometric cell (m). Making the assumption that, in filtered samples, essentially all of the absorption in the cell occurs due to $\mathrm{CDOM}$, (i.e. $a_{\mathrm{g}} \approx a_{\mathrm{t}}$ ) this equation can be simplified to

$Q_{\mathrm{a}}(\lambda)=E_{0}(\lambda) \times S \times\left[1-\exp \left(-a_{\mathrm{g}(\lambda)} \times \ell\right)\right]$.

This rigorous treatment of $Q_{\mathrm{a}}$ is necessary to avoid overestimating the absorption of photons by samples that experience varying light fields over the length of the spectrophotometric cell due to inner filter effects (i.e. self shading) (Hu et al., 2002).

Due to the multispectral nature of these irradiations, an iterative, non-linear fitting routine is used to determine the AQY spectrum (Johannessen and Miller, 2001; Ziolkowski and Miller, 2007; White et al., 2010; Xie et al., 2009). The experimental photochemical production under each cutoff filter is calculated according to the equation

$$
\frac{d P}{d t}(\lambda)=\operatorname{AQY}(\lambda) \cdot Q_{\mathrm{a}}(\lambda)
$$

where $\frac{d P}{d t}$ is the production rate of the product in question $\left(\mathrm{CO}\right.$ or $\left.\mathrm{CO}_{2}\right)$ over the course of the experiment. The spectral equation for the AQY is defined a priori as

$\mathrm{AQY}_{\lambda}=e^{-\left(m_{1}+m_{2}\left(\lambda-m_{3}\right)\right)}$

and initial estimates for the fitting coefficients, $m_{1}, m_{2}$, and $m_{3}$ are taken from literature values (Johannessen and Miller, 2001; Ziolkowski and Miller, 2007). The MATLAB nlinfit routine is used to iteratively find the best fit to the defined AQY equation, adjusting the $m$ coefficients and calculating the single AQY spectrum that best describes all of the different photochemical production values measured in samples 
distributed under the varied spectral irradiation environments created by Schott cutoff filters. Previous published work on $\mathrm{CO}$ and $\mathrm{CO}_{2}$ AQY spectra has shown that this multispectral approach compares well with traditional monochromatic studies, particularly in the important UV region of the spectrum, and both do a credible job of predicting measured full spectrum photochemical production rates (White et al., 2010; Ziolkowski and Miller, 2007).

\subsection{Determination of CDOM-normalized production rates}

As mentioned above, the irradiance spectrum under the $305 \mathrm{~nm}$ cutoff filter most closely matches the spectral distribution of sunlight. Consequently, photoproduction in cells under the $305 \mathrm{~nm}$ cutoff filter can be used as a proxy for photoproduction in sunlight when total photon dose is matched. For some comparisons, we have used photoproduction under the $305 \mathrm{~nm}$ filter (referred to as "measured production") to provide useful insight about the variation of photoproduction in the system. As can be seen clearly in Eqs. (4) and (5) above, it should be noted that measured production is intrinsically linked to both AQY and the absorption coefficient of CDOM in the system with samples having higher $a_{\mathrm{g}}$ generally exhibiting higher measured production without necessarily reflecting differences in photochemical efficiency.

To assess variations in photoproduction due to changes only in the AQY spectrum independently from $a_{\mathrm{g}}$ in the original sample, CDOM normalized production can be calculated, using the photoproduction Eq. (5) where the change in concentration of product per unit time (e.g. $\mathrm{mol} \mathrm{s}^{-1}$ ) is a function of the scalar irradiance, total number of photons absorbed (Eq. 4), and the AQY $(\lambda)$, with each of these quantities being spectrally defined. By employing both a standard absorption spectrum (for this paper we use $a_{\mathrm{g}}$ from the November 2008 Altamaha high tide sample) and a constant, defined scalar irradiance spectrum, we can compare the consequences of variations in the AQY spectrum on photoproduction by integrating Eq. (5) over photochemically active wavelengths $(260 \mathrm{~nm}-490 \mathrm{~nm})$. This allows an evaluation of both the spectral slope coefficient of each AQY spectrum together with its relative magnitude. For consistency, the spectral irradiance used was the same as in the experimental setup, leading to units of production in the spectrophotometric cell of nmol product s ${ }^{-1}$ cell $^{-1}(\sim 30 \mathrm{ml})$. Errors are calculated from the root-mean-square error of the AQY fit, as determined by the nlinfit routine, and propagated through the calculation of CDOM normalized production. It should be noted that these rates are not true environmental rates, but were solely calculated for the purpose of eliminating the variation due to $\mathrm{CDOM}$ and irradiance in the photochemical reactions that would naturally occur in an environmentally rigorous calculation of photoproduction. The purpose of this calculation was to specifically isolate only the effect of changing AQY spectra on photoproduction, and we do not want to mislead the reader by suggesting that these rates are estimates of those found in the coastal waters sampled. For a discussion of the environmentally relevant rates, please refer to Sect. 2.7.

\subsection{Determination of sample optical proxies}

Helms et al. (2008) have shown that the spectral slope coefficient for the exponential best fit of CDOM spectra over the wavelength range $275 \mathrm{~nm}-295 \mathrm{~nm}\left(S_{275-295}\right)$ correlates with the molecular mass of the DOM in a seawater sample. For this CDOM spectral range, a shallow spectral "slope" in the UV indicated larger molecular size while a steep $S_{275-295}$ indicated smaller molecular size. Spectral slope coefficients were determined for our samples using a non-linear fit to the CDOM absorption spectrum over the prescribed wavelengths, 275-295 nm. Using MATLAB's nlinfit routine, the CDOM spectra were fit to the equation

$a_{\mathrm{g}}(\lambda)=B \cdot e^{-S \lambda}$

where $a_{\mathrm{g}}$ is absorption in $\mathrm{m}^{-1}, B$ is a fitting constant, $\lambda$ is wavelength in $\mathrm{nm}$, and $S$ is the spectral slope coefficient.

Specific ultraviolet absorption (SUVA) is the absorption coefficient of CDOM at a specific UV wavelength divided by the total DOC concentration of the same sample. When highly absorbing moieties such as those containing aromatic structures make up a larger fraction of the total DOC pool, SUVA is expected to be elevated over those samples without aromatics. Weishaar et al. (2003) have confirmed this strong positive correlation between DOC \% aromatic content and SUVA at $254 \mathrm{~nm}$ (i.e. SUVA 254 ) in a variety of naturally occurring water samples.

The GCE-LTER nutrient monitoring program collected samples for DOC analysis simultaneously with our photochemical samples (data obtained via http://www.gce-lter. marsci.uga.edu and displayed in Table 1). The absorption spectra of samples prior to irradiation were used to calculate SUVA $_{254}$ using the equation

$\mathrm{SUVA}_{254}=\frac{a_{\mathrm{g}}(254)}{\mathrm{DOC}}$

where $a_{\mathrm{g}}(254)$ is the absorption coefficient at $254 \mathrm{~nm}$ and DOC is the concentration of dissolved organic carbon in $\mathrm{mg} \mathrm{C1^{-1 }}$ reported by the GCE-LTER.

\subsection{Annual photochemical production}

To use our $\mathrm{CO}$ and $\mathrm{CO}_{2} \mathrm{AQY}$ data set for an estimate of the total annual photoproduction of these two oxidation products in the South Atlantic Bight (USA), we employed a photoproduction equation adapted from Fichot and Miller (2010) and Stubbins et al. (2006);

$\sum_{\text {area }} P($ total $)=\int_{290}^{490} E_{d 0-}(\lambda) \cdot R(\lambda) \cdot \operatorname{AQY}(\lambda) \cdot 12$, 

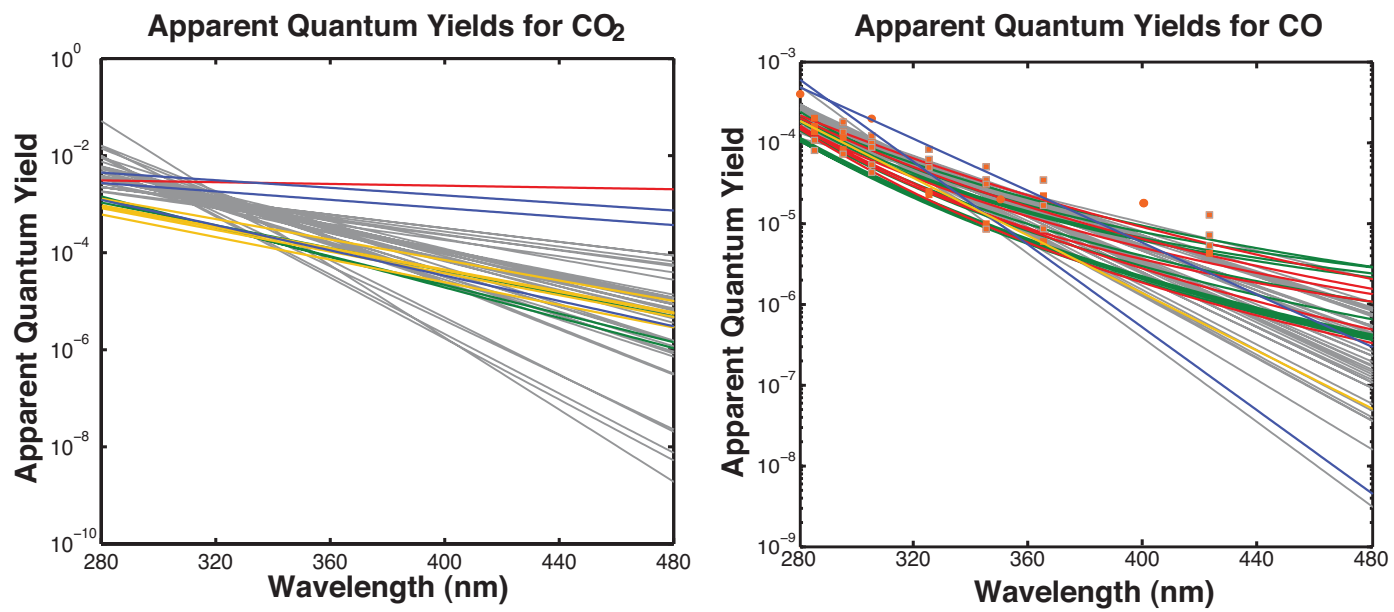

Fig. 2. Apparent quantum yield spectra for $\mathrm{CO}_{2}$ and $\mathrm{CO}$ : grey background lines represent our data set; coloured lines represent literature values. $\mathrm{CO}_{2}$ : red - Skalski (2006), yellow - Aarnos et al. (2012), green - White et al. (2010), blue - Johannessen and Miller (2001). CO: red - Zhang et al. (2006), yellow - Ziolkowski and Miller (2007), green - Xie et al. (2009), blue - Miller et al. (2002), orange squares - Stubbins et al. (2011), orange circles - Valentine and Zepp (1993).

where $P$ (total) is the annual photoproduction rate $(\mathrm{g} \mathrm{C}$ $\mathrm{yr}^{-1} \mathrm{~m}^{-2}$ ) summed over the area of interest, $E_{d 0-}(\lambda)$ is the downwelling spectral irradiance for $30^{\circ} \mathrm{N}$ latitude (mol photons $\mathrm{yr}^{-1} \mathrm{~m}^{-2}$ ) calculated using the STAR model (System for Transfer of Atmospheric Radiation, University of Munich, Ruggaber et al., 1994) following the methodology described in Fichot and Miller (2010), AQY is the "mean" apparent quantum yield spectrum for the chemical species in question (unitless ratio), 12 is the molecular mass of carbon $\left(\mathrm{g} \mathrm{mol}^{-1}\right), \lambda$ is wavelength $(\mathrm{nm})$ and $R(\lambda)$ is the ratio of CDOM absorption to total light attenuation (unitless ratio), as derived from a large coastal and oceanic data set (Fichot, 2004). The ratio follows a linear relationship spectrally:

$R(\lambda)=\frac{a_{\mathrm{g}}(\lambda)}{K_{\mathrm{D}}(\lambda)}=-0.0028(\lambda)+1.575$,

where $a_{\mathrm{g}}$ is absorption $\left(\mathrm{m}^{-1}\right)$ and $K_{\mathrm{D}}$ is the downwelling attenuation coefficient $\left(\mathrm{m}^{-1}\right)$. The "mean" apparent quantum yield spectra were determined by fitting all data from all experiments involving a particular product to the AQY equation (Eq. 6).

\section{Results}

\subsection{Apparent quantum yield spectra and CDOM- normalized photoproduction rates}

Examining our entire AQY data set together shows that results for both $\mathrm{CO}$ and $\mathrm{CO}_{2}$ fall within the range of literature values from previous studies, as shown in Fig. 2. Also, as expected from previous studies, the overall efficiency of $\mathrm{CO}$ production is lower than that seen for $\mathrm{CO}_{2}$ production
Table 2. $\mathrm{CO}_{2}: \mathrm{CO}$ mean production ratios.

\begin{tabular}{cccl}
\hline $\begin{array}{c}\mathrm{CO}_{2} \text { :CO ratio } \\
\text { range }\end{array}$ & $\begin{array}{c}\mathrm{CO}_{2} \text { :CO ratio } \\
\text { mean }\end{array}$ & $\begin{array}{c}\text { Ratio standard } \\
\text { deviation }\end{array}$ & Method used \\
\hline $4.2-73.4$ & 22.5 & 12.5 & $\begin{array}{l}\text { Measured } \\
\text { production } \\
\text { CDOM nor- } \\
\text { malized } \\
\text { production }\end{array}$ \\
\hline
\end{tabular}

over the UV wavelength range (280-400 nm). Additionally, the AQY spectra describing CO efficiency have a tighter distribution than those observed for $\mathrm{CO}_{2}$. Table 1 shows the individual AQY fitting parameters for every sample shown in Fig. 2 together with its associated field data.

$\mathrm{CDOM}$-normalized $\mathrm{CO}$ and $\mathrm{CO}_{2}$ photoproduction rates calculated from our AQY data set for each sample can be seen in Fig. 3. Neither product shows obvious patterns between sites, though there appears to be somewhat more variation among the terrestrially influenced sites (i.e. Doboy Sound and Altamaha Sound) for $\mathrm{CO}_{2}$. CO rates show a seasonal signal at all three sites, with lower production efficiency in the spring and summer months and higher production efficiency in the autumn and winter months for both high and low tide conditions. Considering all sites and tides, the difference between summer and autumn (August and November) is $21.7 \%$ for $\mathrm{CO}$, and is statistically significant (1-way ANOVA, $p<0.01$ ).

\section{2 $\mathrm{CO}_{2}$ to $\mathrm{CO}$ production ratios}

For comparison with previous studies and for potential use in regional coastal photochemical production estimates, the 


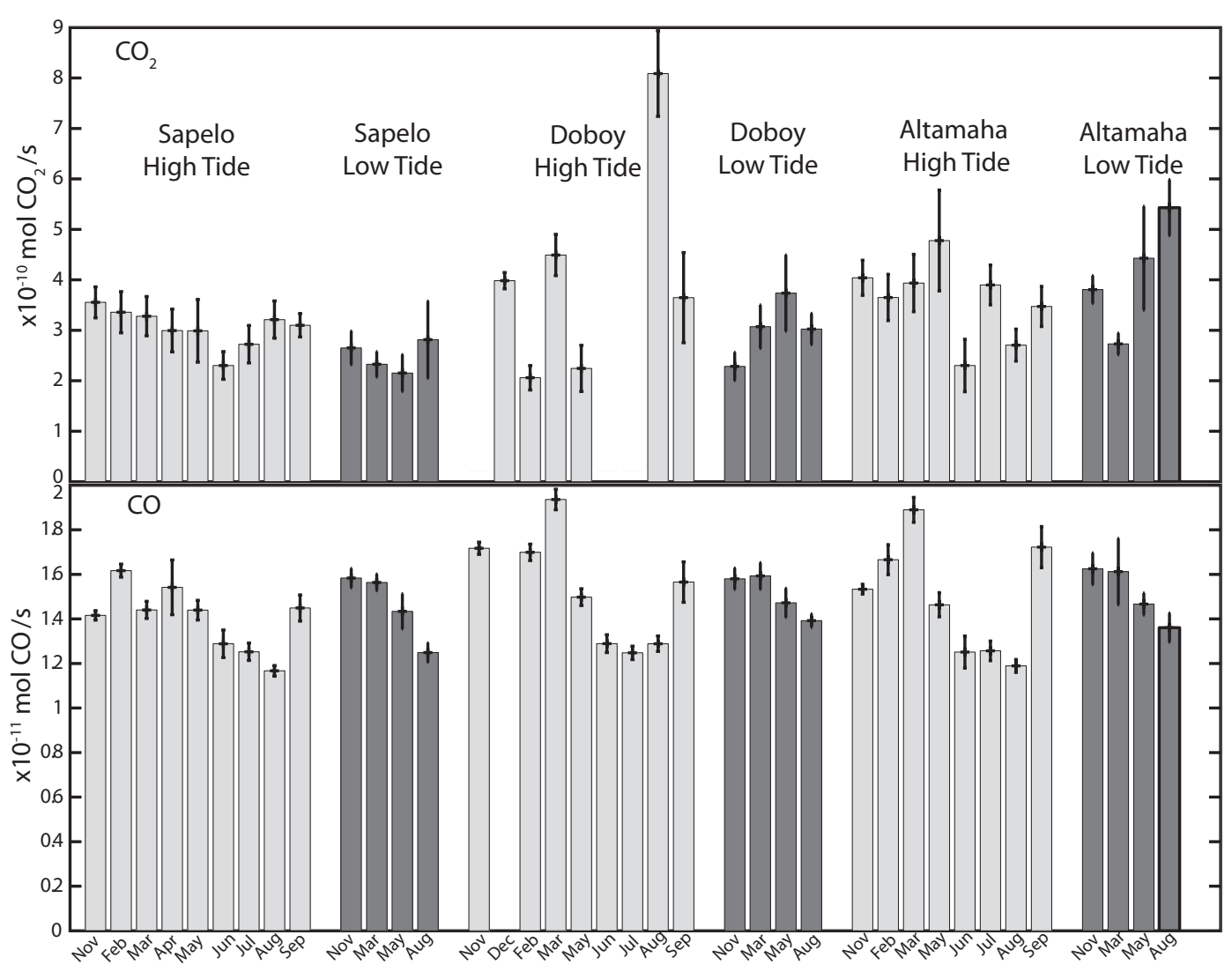

Fig. 3. $\mathrm{CDOM}$ normalized production for $\mathrm{CO}_{2}$ and $\mathrm{CO}$. Error bars represent standard error of AQYs.

ratio between photochemical production of $\mathrm{CO}_{2}$ and $\mathrm{CO}$ was examined in two ways. First, the ratio was calculated using the measured production values $\left(\mathrm{CO}_{2}: \mathrm{CO}_{\text {measured }}\right)$ for each sample. Second, the ratio was calculated from the CDOM-normalized production values for each sample $\left(\mathrm{CO}_{2}: \mathrm{CO}_{\text {normalized }}\right)$ generated from specific AQY spectra and Eq. (7). Values for both ratio methods are presented in Table 2, both showing a similar large ratio range and having nearly identical mean values (22.5 and 23.2).

\subsection{Photochemical production relative to salinity and optical properties}

Figure 4 shows the relationships between photochemical production and salinity. Measured production appears to decrease with increasing salinity for both photochemical products seen in Fig. 4a, but this is likely due to a negative correlation between CDOM and salinity. When normalized for CDOM absorbance (Fig. 4b), there is no relationship between salinity and the efficiency of photochemical production of either product.

Because the absorption of a photon by CDOM must occur for a photochemical reaction to occur, a relationship between CDOM "concentration" and measured production should exist (see Eqs. 4 and 5). Using the absorption coefficient of the sample at $320 \mathrm{~nm}\left(a_{\mathrm{g}} 320, \mathrm{~m}^{-1}\right)$, Fig. 5a shows that samples with higher $a_{\mathrm{g}} 320$ absorb more photons and exhibit a correspondingly higher production of both photochemical products. The relationship between $a_{\mathrm{g}} 320$ and CDOM normalized production, shown in Fig. 5b, shows no such trend for either product with $a_{\mathrm{g}} 320$, indicating that efficiency is relatively constant for all CDOM "concentrations" in this study.

The measured production of both products shows a slight decreasing trend with relation to CDOM spectral slope, but the scatter around this trend in quite large (Fig. 6a). Once production is normalized for CDOM variations (Fig. 6b), there is less scatter than seen with measured production alone, but no trend exists with respect to spectral slope.

Examination of the measured production of both products compared to carbon normalized optical properties using SUVA $_{254}$ (Fig. 7a) also showed a large amount of scatter. The slight positive correlation seen in this relationship is not statistically significant. Again, using CDOM normalized production compared to $\mathrm{SUVA}_{254}$ shows less scatter than measured production, but no trend for either $\mathrm{CO}$ or $\mathrm{CO}_{2}$ was observed, suggesting that, within the range of CDOM and SUVA $_{254}$ values seen in this study, aromatic content does not seem to affect the efficiency for producing $\mathrm{CO}$ and $\mathrm{CO}_{2}$ through photochemical processes (Fig. 7b). 

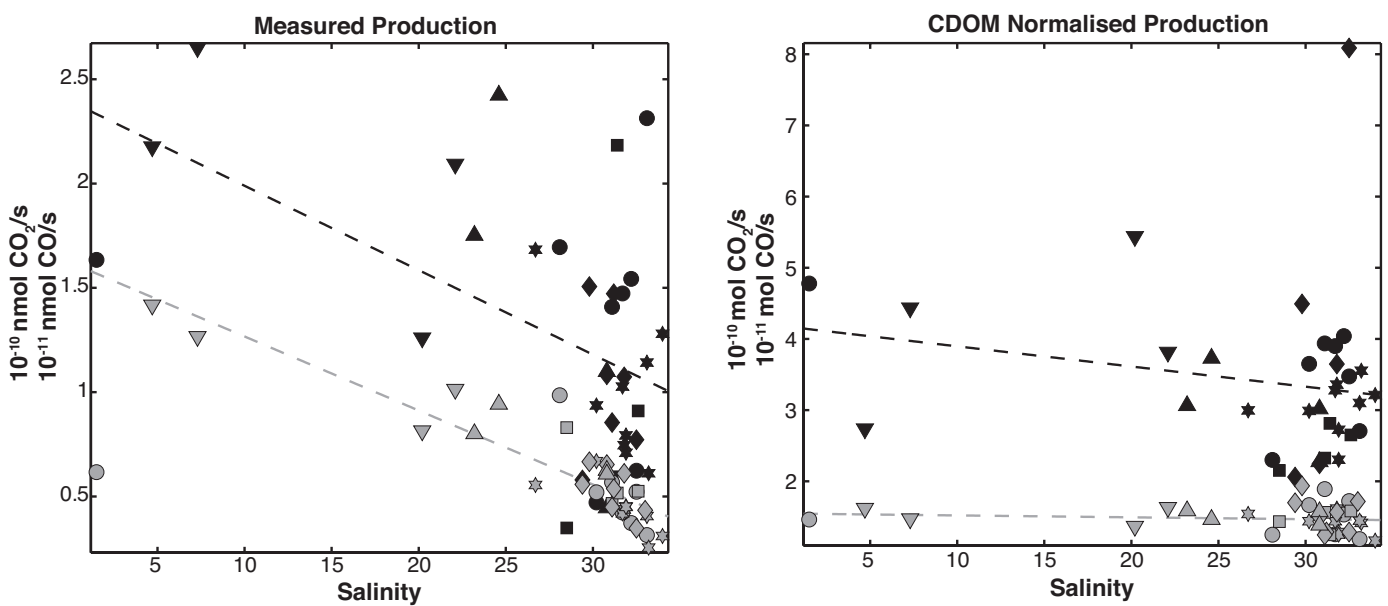

Fig. 4. Measured production and CDOM normalized production with respect to salinity. Black symbols represent $\mathrm{CO}_{2}\left(R^{2}=0.27\right.$ measured, 0.04 normalized) and grey symbols represent CO $\left(R^{2}=0.77\right.$ measured, -0.08 normalized). Symbol key: circle - Altamaha high tide, pointing down triangle - Altamaha low tide, star - Sapelo high tide, square - Sapelo low tide, diamond - Doboy high tide, pointing up triangle - Doboy low tide.
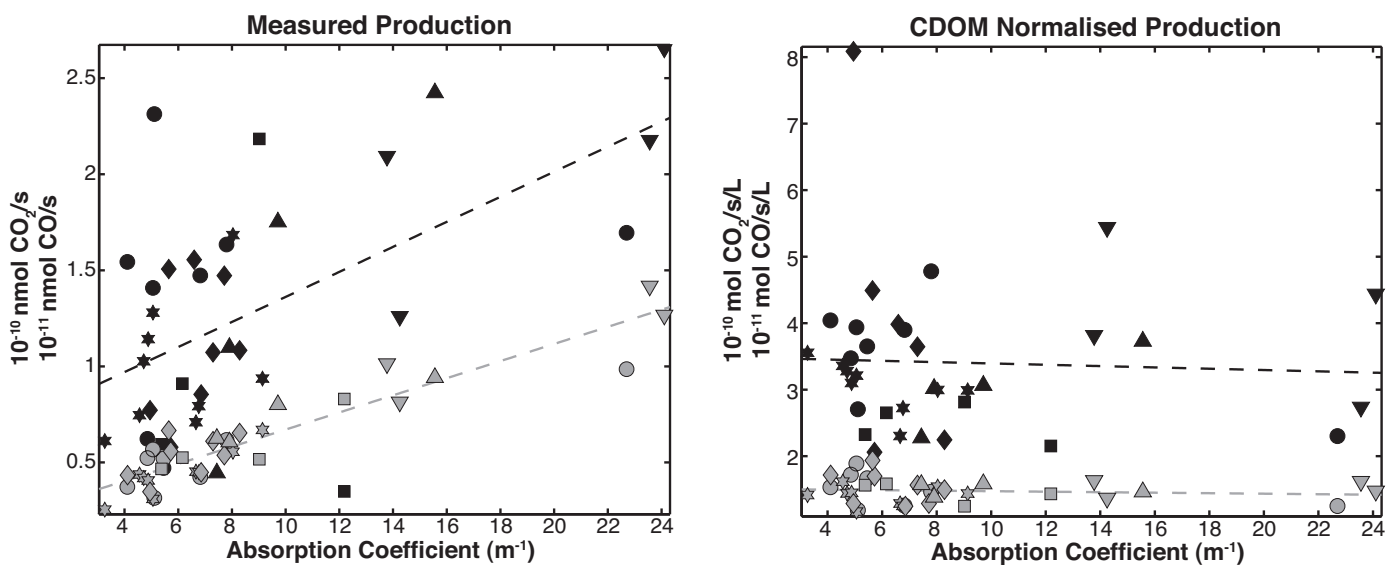

Fig. 5. Measured production and CDOM normalized production with respect to absorption coefficient of sample at $320 \mathrm{~nm}$. Black symbols represent $\mathrm{CO}_{2}\left(R^{2}=0.32\right.$ measured, 0.002 normalized $)$ and grey symbols represent $\mathrm{CO}\left(R^{2}=0.86\right.$ measured, 0.01 normalized $)$. Symbol key: circle - Altamaha high tide, pointing down triangle - Altamaha low tide, star - Sapelo high tide, square - Sapelo low tide, diamond Doboy high tide, pointing up triangle - Doboy low tide.

\subsection{Estimated photochemical production}

Table 3 shows annual photochemical production estimates for the estuaries and inner shelf of the South Atlantic Bight (SABi) using the methods described in Sect. 2.7 and the areal extent values $\left(37.7 \times 10^{9} \mathrm{~m}^{2}\right)$ that Cai $(2011)$ used to calculate inorganic carbon cycling in this coastal region. Photochemical production of $\mathrm{CO}_{2}$ was calculated in two ways. First we used the more easily defined "mean" AQY spectrum for $\mathrm{CO}$ photoproduction from our data to calculate the annual photoproduction of $\mathrm{CO}$ in the SABi as $7.13 \times 10^{9} \mathrm{~g}$ $\mathrm{C} \mathrm{yr}^{-1}$. Then using the mean ratio of $\mathrm{CO}_{2}$ to $\mathrm{CO}$ production from our data (22.5), we calculated the annual SABi photoproduction of $\mathrm{CO}_{2}$ to be $1.60 \times 10^{11} \mathrm{~g} \mathrm{C} \mathrm{yr}^{-1}$. The second method used to estimate photoproduction of $\mathrm{CO}_{2}$ in the $\mathrm{SABi}$ employed the "mean" AQY spectrum obtained directly from our $\mathrm{CO}_{2}$ data set, which gave an annual SABi photoproduction of $1.38 \times 10^{11} \mathrm{~g} \mathrm{C} \mathrm{yr}^{-1}$.

\section{Discussion}

\subsection{Seasonal changes in photoproduction efficiency}

The two sites that experience significant freshwater flow during the year (Doboy and Altamaha sounds) exhibit considerable seasonal variability in their photochemical efficiencies as can be seen by examining their CDOM-normalized production (Fig. 3 top panel) for $\mathrm{CO}_{2}$. The Sapelo Sound samples show considerably less variability. This is likely due to 

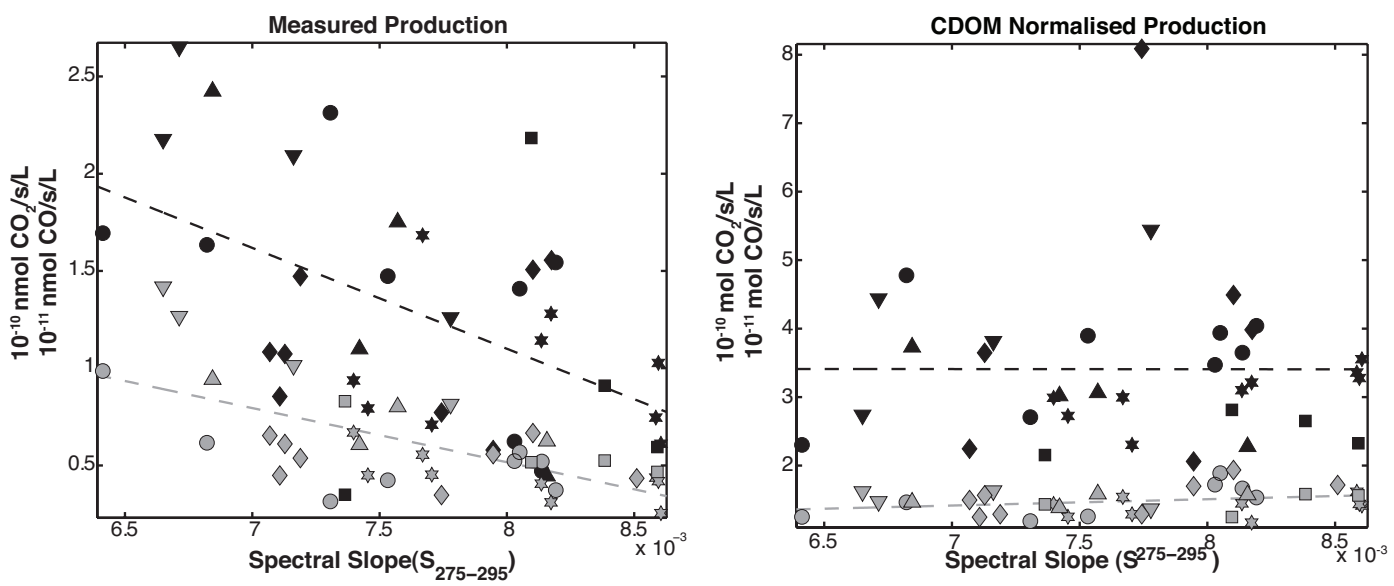

Fig. 6. Measured production and CDOM normalized production with respect to the spectral slope coefficient (275-295 nm). Black symbols represent $\mathrm{CO}_{2}\left(R^{2}=0.26\right.$ measured, $1 \times 10^{-6}$ normalized $)$ and grey symbols represent $\mathrm{CO}\left(R^{2}=0.44\right.$ measured, 0.09 normalized $)$. Symbol key: circle - Altamaha high tide, pointing down triangle - Altamaha low tide, star - Sapelo high tide, square - Sapelo low tide, diamond -Doboy high tide, pointing up triangle - Doboy low tide.
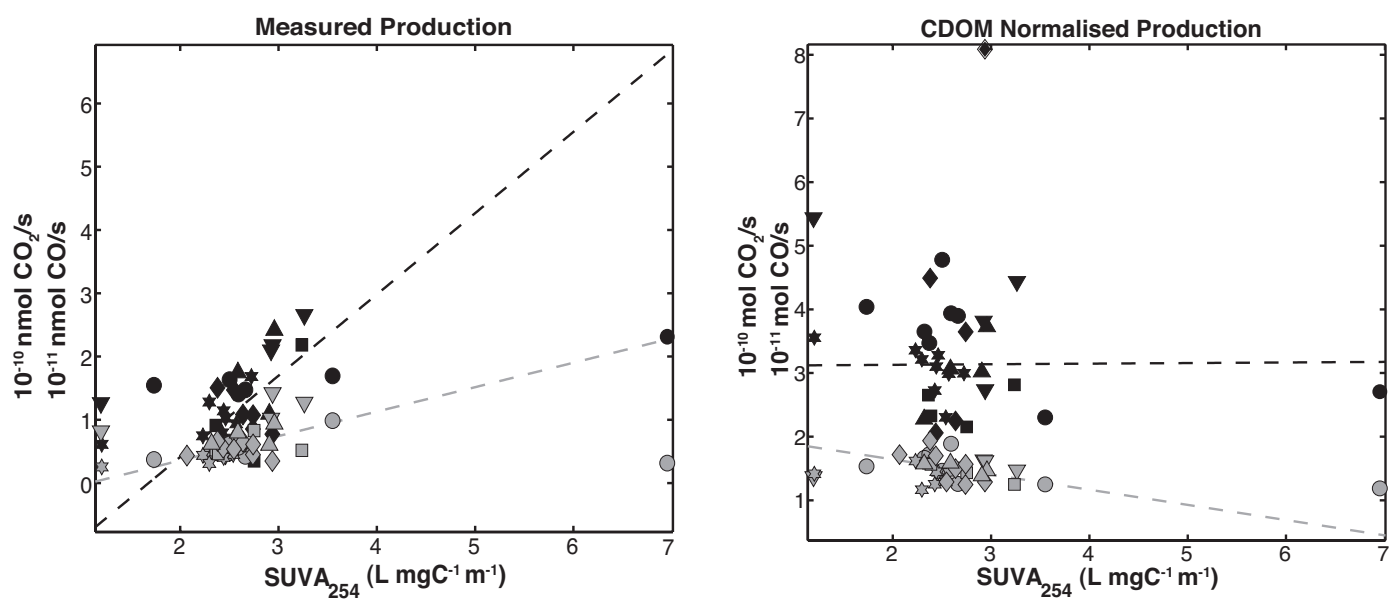

Fig. 7. Measured production and CDOM normalized production with respect to the specific UV absorbance $(254 \mathrm{~nm}) \mathrm{of}$ the sample. Black symbols represent $\mathrm{CO}_{2}\left(R^{2}=0.30\right.$ measured, 0.46 normalized, robust fit down-weighting outliers $)$ and grey symbols represent $\mathrm{CO}\left(R^{2}=\right.$ 0.52 measured, 0.08 normalized). Symbol key: circle - Altamaha high tide, pointing down triangle - Altamaha low tide, star - Sapelo high tide, square - Sapelo low tide, diamond - Doboy high tide, pointing up triangle - Doboy low tide.

the homogeneity of its carbon source material (CDOM) since it is a tidally dominated system with a DOC source dominated by tidal exchange with coastal water and input from surrounding marshes. This is unlike the mixed influence of marsh, riverine, and coastal DOC experienced by Doboy and Altamaha sounds where the Altamaha River delivers upland (i.e. nonmarsh-derived) DOC with a seasonal signal, thus creating a more complex and dynamic DOC system.

Fluctuations in riverine discharge and coastal hydrology may also add to the observed variability of photochemical reactivity in our samples. Due to higher sediment loads and reduced residence times during high-flow events in the Altamaha River, CDOM reaching our sampling sites during these periods would have minimal pre-exposure to sunlight and could influence its photochemical reactivity relative to CDOM delivered during low-flow conditions with a longer pre-exposure to sunlight. It is also documented that estuarine iron is usually positively correlated with river flow and particulate loading (e.g. Lippiatt et al., 2010) and that its complexation with DOM can greatly affect photochemical reactions in estuarine systems (Gao and Zepp, 1998; White et al., 2003). These potential variations in the chemical nature of CDOM would certainly add to the variation of AQY in coastal systems and may not be directly related to salinity.

CDOM normalized photoproduction of $\mathrm{CO}$ shows less variability than does $\mathrm{CO}_{2}$ across all samples, suggesting that the molecular source that dominates $\mathrm{CO}$ production is more homogenous throughout these coastal and estuarine samples 
Table 3. Annual photoproduction calculated for the estuaries and inner shelf of the South Atlantic Bight $(\mathrm{SABi})$ for $\mathrm{CO}_{\text {and }} \mathrm{CO}_{2}$.

\begin{tabular}{ccl}
\hline Photoproduct & Annual SAB production $\left(\mathrm{g} \mathrm{C} \mathrm{yr}^{-1}\right)$ & Method used \\
\hline $\mathrm{CO}$ & $7.13 \times 10^{9}$ & "Mean" AQY \\
$\mathrm{CO}_{2}$ & $1.36 \times 10^{11}$ & "Mean" AQY \\
$\mathrm{CO}_{2}$ & $1.60 \times 10^{11}$ & $\mathrm{CO}_{2}: \mathrm{CO}$ measured production ratio \\
\hline
\end{tabular}

than that responsible for $\mathrm{CO}_{2}$ photoproduction. Another possible source of this larger $\mathrm{CO}_{2}$ variation is that the chromophores within CDOM that initiate $\mathrm{CO}$ photoproduction vary more directly with overall CDOM absorbance than do the chromophores responsible for $\mathrm{CO}_{2}$ photoproduction. In such a case, using CDOM to normalize photoproduction would create a larger variation in normalized $\mathrm{CO}_{2}$ production than in CO. This would be compatible with reported positive correlations between $\mathrm{CO}$ photoproduction and aromatic content (Stubbins et al., 2008), a natural chromophore thought to be a very strong contributor to the overall CDOM absorbance.

All three sampling sites showed a decrease in photochemical production efficiency for $\mathrm{CO}$ in the spring and summer with an increase in the autumn and winter months. While the total variation is small $(21.7 \%$ between November and August over all sites and tides), it is a statistically significant change. In Georgia, the marshes are dominated by the smooth cordgrass Spartina alterniflora that is highly productive in the spring and summer months and undergoes senescence beginning in September and October. Autumn, therefore, represents a period of increased organic matter input to the ocean from the marshes, a situation similar to Gardner et al. (2005) in the Neponset River estuary. This increased flux of organic carbon into the system may help to explain the higher efficiency of $\mathrm{CO}$ photoproduction in the autumn and winter months. Interestingly, this trend is seen at all three sites for $\mathrm{CO}$, suggesting that marsh-derived DOC may be the dominant control on the seasonal variability of AQY for $\mathrm{CO}$ photoproduction. Additionally, this seasonal trend with lower efficiencies seen in the summer months could be driven by increased solar irradiation and pre-exposure of the CDOM to extensive sunlight, leading to photobleaching and potentially lowering the efficiency of the photochemical reaction. CDOM released in the autumn and winter months would have less prior exposure to sunlight and this could lead to the higher efficiencies seen in those months. In reality, both of these situations are likely to co-exist. The lack of significant seasonality and larger variability seen in the $\mathrm{CO}_{2}$ photoproduction data could indicate a more even dependence on riverine, marsh, and coastal derived carbon. Offsets and overlaps in seasonal river input with marsh productivity and senescence may explain the increased variability between sites and seasons seen for $\mathrm{CO}_{2}$ photochemistry in this coastal system. Interestingly, Aarnos et al. (2012) did not find any seasonality in their $\mathrm{CO}_{2}$ (measured as DIC) apparent quantum yields in the Baltic Sea, despite the expectation that photochemical bleaching in the summer may affect the AQYs for $\mathrm{CO}_{2}$, though they attributed the effect to such small seasonality as to not be measurable with current techniques. In the current study, however, the variability between samples is the dominant characteristic of the $\mathrm{CO}_{2}$ AQYs.

\subsection{Production ratios}

While some estimates of regional and global photochemical production of $\mathrm{CO}_{2}$ have been made (Mopper and Kieber, 2000; Miller and Zepp, 1995), these are generally based on ratios between $\mathrm{CO}_{2}$ and $\mathrm{CO}$ photoproduction, taking advantage of comparatively well-defined $\mathrm{CO}$ photoproduction estimates. The first study to define a ratio between $\mathrm{CO}_{2}$ and $\mathrm{CO}$ photoproduction reported values between 15 and 20 $\left(\mathrm{CO}_{2}: \mathrm{CO}\right)$ (Miller and Zepp, 1995), suggesting that $\mathrm{CO}_{2}$ is a dominant carbon photoproduct resulting from the irradiation of CDOM. To date, this has been the only study where $\mathrm{CO}$ and $\mathrm{CO}_{2}$ were measured from the same experimental exposure cell at the same time. Consequently, the question remains as to what effect the absence of the carbonate system, required for the $\mathrm{CO}_{2}$ analysis, and small differences in $\mathrm{pH}$ may have on measured photoproduction of $\mathrm{CO}$. More recent studies have shown that the ratio between $\mathrm{CO}_{2}$ and $\mathrm{CO}$ photoproduction is more variable and can range from 2 to 98 depending on the water type (White et al., 2010). In this study, the ratio of $\mathrm{CO}_{2}$ to $\mathrm{CO}$ was calculated in two different ways, giving mean ratios of 22.5 (measured production) and 23.2 (CDOM normalized) (see Table 2). While the overall range of $\mathrm{CO}_{2}$ : $\mathrm{CO}$ ratios was large (4-73 (measured production), 12-62 (CDOM normalized)), it agrees well with the ratios reported in Miller and Zepp (1995) (12-65) with a mean of 20. Miller and Zepp (1995) found that pre-faded samples showed smaller $\mathrm{CO}_{2}$ to $\mathrm{CO}$ production ratios. Preexposure of the CDOM to sunlight could explain the variation of $\mathrm{CO}_{2}$ to $\mathrm{CO}$ production ratios in the present study since samples from riverine sources, presumably having had less sunlight-exposure, showed higher ratios (see Fig. 3) than samples from the more coastal Sapelo Sound site, which likely received more solar irradiation prior to sample collection. Regardless of the cause, it is clear from our spatiotemporal study that $\mathrm{CO}_{2}$ photoproduction is more variable than CO photoproduction (Figs. 2, 3). This is consistent with both $\mathrm{CO}_{2}$ AQY spectra being more affected by pre-exposure to sunlight than CO AQY spectra, and differing molecular 
compositions of the source material for the two different photoproducts as discussed above in Sect. 4.1.

\subsection{Water sample characteristics and their relationship to photoproduction efficiencies}

Salinity has been suggested as a potential tracer for AQY variations in studies such as Xie et al. (2009) in the Beaufort Sea and Zhang et al. (2006) in the St. Lawrence River estuary. Each have shown a decrease in the photochemical efficiency of $\mathrm{CO}$ production with decreasing salinity. Stubbins et al. (2011) also found an inverse trend between CO AQYs and salinity in the Tyne River estuary. This was not explained by simple conservative mixing and suggests that this relationship is more strongly tied to CDOM. Conversely, this trend was not seen by White et al. (2010) in the Delaware River estuary where they reported nearly constant photochemical efficiencies (AQY at $330 \mathrm{~nm}$ ) for both $\mathrm{CO}_{2}$ and $\mathrm{CO}$ throughout the estuary, with the exception of a strong increase for both products at a salinity of zero in the Delaware River. The current study shows no indication of varying photochemical efficiencies with salinity for either product. This may reflect the limited salinity range that describes the vast majority of our samples, with most falling between 20 and 33. Without larger and more evenly distributed salinity data such as that examined by Zhang et al. (2006) and Xie et al. (2009) (salinities from 0 to 35) as well as White et al. (2010) (salinities from 0 to 23), any salinity related AQY variation present in our samples would be very difficult to define.

The clear increase in photoproduction with increasing CDOM absorption is expected (see Eq. 7) and could correlate with changes in $\mathrm{CO}$ and $\mathrm{CO}_{2}$ production efficiency. However, the CDOM normalized production data show no such trend for either product, indicating that $\mathrm{CDOM}$ in darker waters is neither more nor less efficient at producing $\mathrm{CO}$ and $\mathrm{CO}_{2}$ than CDOM in less absorptive samples (Fig. 5). This is in contrast to other studies in the St. Lawrence River estuary (Zhang et al., 2006), the Beaufort Sea (Xie and Zafiriou, 2009) and the Tyne River estuary (Stubbins et al., 2011). These studies did not address $\mathrm{CO}_{2}$ photochemistry, but all three found an increase in CO AQY values with increasing CDOM absorption coefficients using transect data from high absorption (upper estuary) to low absorption (coastal) waters. In contrast, results from our coastal study do not represent transect data from upper estuaries to the open ocean taken over a short time period, but rather repeated sampling of specific estuarine locations over the course of a year. The constant efficiency of $\mathrm{CO}$ photoproduction over all samples seen in our yearlong investigation is consistent with a relatively homogenous influence of marsh-derived carbon at all three sites.

While the measured production in this study shows a slight decrease for both $\mathrm{CO}$ and $\mathrm{CO}_{2}$ with increasing spectral slope, there is no such trend with CDOM normalized production for either photoproduct (Fig. 6). If, in fact, spectral slope values reflect molecular size variations over the sample range col- lected in this study, the lack of trend with CDOM normalized photoproduction suggests that it does not affect photochemical efficiency for either photoproduct. The E2:E3 ratio (i.e. the ratio between absorption at $254 \mathrm{~nm}$ and $365 \mathrm{~nm}$ ) is similar to spectral slope, and has been shown to be an indicator of the charge-transfer character of CDOM (Del Vecchio and Blough, 2004). Del Vecchio and Blough (2004) have shown that increased absorption at long wavelengths is an indication of higher charge-transfer character. This charge-transfer character has been shown to be a potential predictor of the photochemical activity of reactive oxygen species, such as ${ }^{1} \mathrm{O}_{2}$ and $\mathrm{H}_{2} \mathrm{O}_{2}$ AQYs (Dalrymple et al., 2010; Sharpless, 2012). We investigated the relationship between our $\mathrm{CO}$ and $\mathrm{CO}_{2}$ reaction efficiencies and $\mathrm{E} 2 \mathrm{E} 3$, but found that there was no significant relationship between them (data not shown). As with the spectral slope, it is possible that the limited range of E2:E3 ratios present in our data set (4.95-7.24) is not enough to show a definitive relationship.

Stubbins et al. (2008) showed that the aromaticity of a sample was positively correlated with increased photoproduction of carbon monoxide. While aromatic content was not directly measured in this study, Weishaar et al. (2003) demonstrated a strong positive linear relationship between $\mathrm{SUVA}_{254}$ and aromatic content of natural water samples. Examining this relationship between $\mathrm{SUVA}_{254}$ (as a proxy for aromatic content) and measured $\mathrm{CO}$ and $\mathrm{CO}_{2}$ photoproduction showed a slight positive correlation as expected based on the work by Stubbins et al. (2008). However, due to the small range of $\mathrm{SUVA}_{254}$ values measured in our sampling regime, this relationship did not prove to be statistically significant. The photochemical production efficiency, as indicated by CDOM-normalized photoproduction for both $\mathrm{CO}$ and $\mathrm{CO}_{2}$, showed no statistically significant relationship with aromaticity, although a slight indication of a negative correlation can be seen in Fig. 7 for CO. Zhang et al. (2006) showed that $\mathrm{SUVA}_{254}$ was a good indicator of the efficiency of CO photoproduction in the St. Lawrence River estuary, showing a significant positive correlation. The $\mathrm{SUVA}_{254}$ values obtained by Zhang et al. (2006), however, were higher (4-7) and spanned a larger range than those from our study of the Georgia coast where most $\mathrm{SUVA}_{254}$ values were concentrated in the 2-3 range. This smaller range of $\mathrm{SUVA}_{254}$ and variability in our data set makes it less likely that robust trends can be defined.

\subsection{Contribution of photochemistry to the coastal system}

Based on previous estimates (White et al., 2010; Johannessen and Miller, 2001; Miller and Zepp, 1995), there is a strong potential for photochemistry to significantly impact the coastal and global cycling of DOC by formation of inorganic carbon in the form of $\mathrm{CO}$ and $\mathrm{CO}_{2}$. In this study, photochemistry was found to contribute to the direct oxidation of DOC in the estuaries and inner shelf for the South 
Atlantic Bight (SABi) by conversion of $7.13 \times 10^{9} \mathrm{~g} \mathrm{C} \mathrm{yr}^{-1}$ in the form of $\mathrm{CO}$, along with $1.60 \times 10^{11} \mathrm{~g} \mathrm{C} \mathrm{yr}^{-1}$ in the form of $\mathrm{CO}_{2}$. Calculations using our "mean" $\mathrm{AQY}$ give a slightly smaller estimate for the contribution of photochemistry in the form of $\mathrm{CO}_{2}$. The ratio method for calculating $\mathrm{CO}_{2}$ photoproduction in the ocean is often used for open ocean and global calculations due to the lack of reliable AQY data for $\mathrm{CO}_{2}$ in blue water marine systems. Adding $\mathrm{CO}$ and $\mathrm{CO}_{2}$ photoproduction together, the contribution of photochemistry to the formation of inorganic carbon products is between $1.46 \times 10^{11} \mathrm{~g} \mathrm{C} \mathrm{yr}^{-1}$ and $1.67 \times 10^{11} \mathrm{~g} \mathrm{C}$ $\mathrm{yr}^{-1}$ in the SABi. Cai (2011) and Jiang et al. (2008a), using field measurements of in situ $\mathrm{CO}_{2}$ saturation state, found this same area to be a source of $\mathrm{CO}_{2}$ to the atmosphere, degassing $2.29 \times 10^{12} \mathrm{~g} \mathrm{C} \mathrm{yr}^{-1}$ to the atmosphere. This result is supported by estimates of remineralization rates in a heterotrophic ecosystem (Cai, 2011). Using Cai's (2011) values for comparison, photochemical production of inorganic carbon products in this system could contribute between $6.4 \%$ to $7.3 \%$ of the total inorganic carbon signal annually.

Based on numbers from Hopkinson (1988), Alberts and Takacs (1999); Moran et al. (1999), the total DOC input to the entire South Atlantic Bight annually is $5.1 \times 10^{12} \mathrm{~g} \mathrm{C} \mathrm{yr}^{-1}$ (Cai, 2011), with the majority ( $\sim 86 \%$ ) of this carbon being marsh-derived DOC. A significant portion of this organic carbon is transformed, presumably by heterotrophic bacteria, to inorganic carbon during its transit from marsh and river to the open ocean (Cauwet, 2002). Comparing the magnitude of DOC input to photochemical estimates, it is possible that between $2.9 \%$ and $3.3 \%$ of this carbon annually may be directly removed from the DOC pool by photochemical oxidation to $\mathrm{CO}$ and $\mathrm{CO}_{2}$ in the $\mathrm{SABi}$.

\section{Conclusions}

The extensive nature of this AQY data set contributes improved constraints for the spatiotemporal variability of both $\mathrm{CO}$ and $\mathrm{CO}_{2}$ photochemical production in the subtropical coastal ocean. It represents a longer-term examination of coastal CO photochemistry than the much more common transect studies published to date. The photochemical efficiency of CO production over all Georgia coastal estuarine environments studied varied annually within $21.7 \%$ with a seasonal pattern. The variation observed in our $\mathrm{CO}_{2}$ data set is overall larger than that for CO. The Sapelo Sound samples that should be most representative of offshore coastal waters, however, showed a $\mathrm{CO}_{2}$ photoproduction constrained to within $9.6 \%$ year-round. The average $\mathrm{CO}_{2}$ to $\mathrm{CO}$ photoproduction ratio for this study was $\sim 23$. Together, these findings allow for better constraints on estimates of the direct influence of photochemistry in coastal organic carbon models. Our calculations indicate the potential for direct mineralization of DOC by photochemical oxidation to inorganic gases in the SABi from $2.9 \%$ to $3.3 \%$. This suggests that photo- chemical oxidation in estuarine and coastal environments is a small but potentially significant contributor to coastal carbon cycling.

Acknowledgements. The authors would like to thank the GCELTER for sampling assistance and S. B. Joye, and K. S. Hunter for the use of the dissolved organic carbon data. The authors would also like to thank the three anonymous reviewers whose constructive comments helped to improve this paper. This work was supported by NASA grant number NNX07AD85G, as part of the North American Carbon Project.

Edited by: C. Robinson

\section{References}

Aarnos, H., Ylostalo, P., and Vahatalo, A. V.: Seasonal phototransformation of dissolved organic matter to ammonium, dissolved inorganic carbon, and labile substrates supporting bacterial biomass across the Baltic Sea, J. Geophys. Res.-Biogeosciences, 117, G01004, doi:10.1029/2010jg001633, 2012.

Alberts, J. J. and Takacs, M.: Importance of humic substances for carbon and nitrogen transport into southeastern United States estuaris, Organic Geochemistry, 30, 385-395, 1999.

Andrews, S. S., Caron, S., and Zafiriou, O. C.: Photochemical oxygen consumption in marine waters: A major sink for colored dissolved organic matter?, Limnol. Oceanogr., 45, 267-277, 2000.

Anesio, A. M. and Graneli, W.: Increased photoreactivity of DOC by acidification: Implications for the carbon cycle in humic lakes, Limnol. Oceanogr., 48, 735-744, 2003.

Anesio, A. M. and Graneli, W.: Photochemical mineralization of dissolved organic carbon in lakes of differing $\mathrm{pH}$ and humic content, Archiv Fur Hydrobiologie, 160, 105-116, doi:10.1127/0003-9136/2004/0160-0105, 2004.

Barbeau, K.: Photochemistry of organic iron(III) complexing ligands in oceanic systems, Photochemistry and Photobiology, 82, 1505-1516, doi:10.1562/2006-06-16-ir-935, 2006.

Barbeau, K., Rue, E. L., Trick, C. G., Bruland, K. T., and Butler, A.: Photochemical reactivity of siderophores produced by marine heterotrophic bacteria and cyanobacteria based on characteristic Fe(III) binding groups, Limnol. Oceanogr., 48, 1069-1078, 2003.

Belanger, S., Xie, H. X., Krotkov, N., Larouche, P., Vincent, W. F., and Babin, M.: Photomineralization of terrigenous dissolved organic matter in Arctic coastal waters from 1979 to 2003: Interannual variability and implications of climate change, Global Biogeochemical Cycles, 20, Gb4005, doi:10.1029/2006gb002708, 2006.

Bertilsson, S. and Tranvik, L. J.: Photochemical transformation of dissolved organic matter in lakes, Limnol. Oceanogr., 45, 753$762,2000$.

Blough, N. V. and Zepp, R. G.: Reactive oxygen species in natural waters, in: Active oxygen: Reactive oxygen species in chemistry, edited by: Foote, C. S., Chapman and Hall, 280-333, 1995.

Bricaud, A., Morel, A., and Prieur, L.: Absorption by dissolved organic matter of the sea (yellow substance) in the UV and visible domains, Limnol. Oceanogr., 26, 43-53, 1981. 
Cai, W. J.: Estuarine and Coastal Ocean Carbon Paradox: CO2 Sinks or Sites of Terrestrial Carbon Incineration?, Annual Review of Marine Science, 3, 123-145, doi:10.1146/annurevmarine-120709-142723, 2011.

Canadell, J. G., Le Quere, C., Raupach, M. R., Field, C. B., Buitenhuis, E. T., Ciais, P., Conway, T. J., Gillett, N. P., Houghton, R. A., and Marland, G.: Contributions to accelerating atmospheric $\mathrm{CO} 2$ growth from economic activity, carbon intensity, and efficiency of natural sinks, Proc. Natl. Acad. Sci. USA, 104, 1886618870, doi:10.1073/pnas.0702737104, 2007.

Carlson, C. A.: Production and Removal Processes, in: Biogeochemistry of Marine Dissolved Organic Matter, edited by: Hansell, D. A. and Carlson, C. A., Academic Press, San Diego, 91-152, 2002.

Cauwet, G.: DOM in the Coastal Zone, in: Biogeochemistry of Marine Dissolved Organic Matter, edited by: Hansell, D. A. and Carlson, C. A., Academic Press, San Diego, 579-609, 2002.

Clark, C. D., Hiscock, W. T., Millero, F. J., Hitchcock, G., Brand, L., Miller, W. L., Ziolkowski, L., Chen, R. F., and Zika, R. G.: CDOM distribution and $\mathrm{CO} 2$ production on the southwest Florida shelf, Marine Chemistry, 89, 145-167, doi:10.1016/j.marchem.2004.02.011, 2004.

Dalrymple, R. M., Carfagno, A. K., and Sharpless, C. M.: Correlations between Dissolved Organic Matter Optical Properties and Quantum Yields of Singlet Oxygen and Hydrogen Peroxide, Environ. Sci. Technol., 44, 5824-5829, doi:10.1021/es101005u, 2010.

Day, D. A. and Faloona, I.: Carbon monoxide and chromophoric dissolved organic matter cycles in the shelf waters of the northern California upwelling system, J. Geophys. Res.-Oceans, 114, C01006, doi:10.1029/2007jc004590, 2009.

Del Vecchio, R. and Blough, N. V.: Photobleaching of chromophoric dissolved organic matter in natural waters: kinetics and modeling, Marine Chemistry, 78, 231-253, 2002.

Del Vecchio, R. and Blough, N. V.: On the origin of the optical properties of humic substances, Environ. Sci. Technol., 38, 38853891, doi:10.1021/es049912h, 2004.

Fabry, V. J., Seibel, B. A., Feely, R. A., and Orr, J. C.: Impacts of ocean acidification on marine fauna and ecosystem processes, Ices Journal of Marine Science, 65, 414-432, doi:10.1093/icesjms/fsn048, 2008.

Fichot, C. G.: Marine Photochemistry From Space: Algorithms for the Retrieval of Diffuse Attenuation and CDOM Absorption Coefficients (320-490 nm) from Ocean Color and Estimation of Depth-resolved Photoproduction Rates of Carbon Monoxide (CO) at Global Scales using SeaWiFS Imagery, MSc, Department of Oceanography, Dalhousie University, Halifax, Nova Scotia, 230 pp., 2004.

Fichot, C. G. and Miller, W. L.: An approach to quantify depthresolved marine photochemical fluxes using remote sensing: Application to carbon monoxide (CO) photoproduction, Remote Sens. Environ., 114, 1363-1377, doi:10.1016/j.rse.2010.01.019, 2010.

Gao, H. Z. and Zepp, R. G.: Factors influencing photoreactions of dissolved organic matter in a coastal river of the southeastern United States, Environ. Sci. Technol., 32, 2940-2946, 1998.

Gardner, G. B., Chen, R. F., and Berry, A.: High-resolution measurements of chromophoric dissolved organic matter (CDOM) in the Neponset River Estuary, Boston Harbor, MA, Marine Chem- istry, 96, 137-154, doi:10.1016/j.marchem.2004.12.006, 2005.

Goldstone, J. V., Del Vecchio, R., Blough, N. V., and Voelker, B. M.: A multicomponent model of chromophoric dissolved organic matter photobleaching, Photochemistry and Photobiology, 80, 52-60, 2004.

Graneli, W., Lindell, M., De Faria, B. M., and Esteves, F. D.: Photoproduction of dissolved inorganic carbon in temperate and tropical lakes - dependence on wavelength band and dissolved organic carbon concentration, Biogeochemistry, 43, 175-195, 1998.

Guo, X. H., Dai, M. H., Zhai, W. D., Cai, W. J., and Chen, B. S.: CO2 flux and seasonal variability in a large subtropical estuarine system, the Pearl River Estuary, China, J. Geophys. Res.-Biogeosciences, 114, G03013, doi:10.1029/2008jg000905, 2009.

Hansell, D. A., Carlson, C. A., Repeta, D. J., and Schlitzer, R.: Dissolved organic matter in the ocean: a controversy stimulates new insights, Oceanography, 22, 202-211, 2009.

Helms, J. R., Stubbins, A., Ritchie, J. D., Minor, E. C., Kieber, D. J., and Mopper, K.: Absorption spectral slopes and slope ratios as indicators of molecular weight, source, and photobleaching of chromophoric dissolved organic matter, Limnol. Oceanogr., 53, 955-969, 2008.

Hopkinson, C. S.: Patterns of organic carbon exchange between coastal ecosystems - the mass balance approach in salt marsh ecosystems, in: Coastal Offshore Ecosystem Interactions.Lecture Notes on Coastal and Estuarine Studies, edited by: Jansson, B. O., Springer, Berlin, 122-154, 1988.

Hu, C. M., Muller-Karger, F. E., and Zepp, R. G.: Absorbance, absorption coefficient, and apparent quantum yield: A comment on common ambiguity in the use of these optical concepts, Limnol. Oceanogr., 47, 1261-1267, 2002.

Jiang, L. Q., Cai, W. J., and Wang, Y. C.: A comparative study of carbon dioxide degassing in river- and marine-dominated estuaries, Limnol. Oceanogr., 53, 2603-2615, 2008a.

Jiang, L. Q., Cai, W. J., Wanninkhof, R., Wang, Y. C., and Luger, H.: Air-sea $\mathrm{CO}_{2}$ fluxes on the US South Atlantic Bight: Spatial and seasonal variability, J. Geophys. Res.-Oceans, 113, C07019, doi:10.1029/2007jc004366, 2008b.

Johannessen, S. C.: A photochemical sink for dissolved organica carbon in the ocean, PhD, Department of Oceanograpy, Dalhousie University, Halifax, 2000.

Johannessen, S. C. and Miller, W. L.: Quantum yield for the photochemical production of dissolved inorganic carbon in seawater, Marine Chemistry, 76, 271-283, 2001.

Kieber, D. J., McDaniel, J., and Mopper, K.: Photochemical source of biological substrates in sea-water - implications for carbon cycling, Nature, 341, 637-639, 1989.

Kieber, R. J., Zhou, X. L., and Mopper, K.: Formation of carbonyl compounds from UV-induced photodegradation of humic substances in natural waters - fate of riverine carbon in the sea, Limnol. Oceanogr., 35, 1503-1515, 1990.

Kitidis, V., Tilstone, G. H., Smyth, T. J., Torres, R., and Law, C. S.: Carbon monoxide emission from a Mauritanian upwelling filament, Marine Chemistry, 127, 123-133, doi:10.1016/j.marchem.2011.08.004, 2011.

Lippiatt, S. M., Brown, M. T., Lohan, M. C., Berger, C. J. M., and Bruland, K. W.: Leachable particulate iron in the Columbia River, estuary, and near-field plume, Est. Coast. Shelf Sci., 87, 
33-42, doi:10.1016/j.ecss.2009.12.009, 2010.

Ludwig, W., Probst, J. L., and Kempe, S.: Predicting the oceanic input of organic carbon by continental erosion, Global Biogeochem. Cycles, 10, 23-41, 1996.

Micinski, E., Ball, L. A., and Zafiriou, O. C.: Photochemical oxygen activation - superoxide radical detection and production-rates in the eastern Carribean, J. Geophys. Res.-Oceans, 98, 2299-2306, 1993.

Miller, W. L. and Moran, M. A.: Interaction of photochemical and microbial processes in the degradation of refractory dissolved organic matter from a coastal marine environment, Limnol. Oceanogr., 42, 1317-1324, 1997.

Miller, W. L. and Zepp, R. G.: Photochemical production of dissolved inorganic carbon from terrestrial organic matter - significance to the oceanic organic carbon cycle, Geophys. Res. Lett., 22, 417-420, 1995.

Miller, W. L., Moran, M. A., Sheldon, W. M., Zepp, R. G., and Opsahl, S.: Determination of apparent quantum yield spectra for the formation of biologically labile photoproducts, Limnol. Oceanogr., 47, 343-352, 2002.

Moffett, J. W. and Zafiriou, O. C.: The photochemical decomposition of hydrogen-peroxide in surface waters of the eastern Carribean and Orinoco River, J. Geophys. Res.-Oceans, 98, 23072313, 1993.

Mopper, K. and Kieber, D. J.: Marine photochemistry and its impact on carbon cycling, in: The effects of UV radiation in the marine environment, edited by: De Mora, S. J., Demers, S., and Vernet, M., Cambridge University Press, Cambridge, UK, 101-129, 2000.

Moran, M. A., Sheldon, W. M., and Sheldon, J. E.: Biodegradation of riverine dissolved organic carbon in five estuaries of the southeastern United States, Estuaries, 22, 55-64, 1999.

Moy, A. D., Howard, W. R., Bray, S. G., and Trull, T. W.: Reduced calcification in modern Southern Ocean planktonic foraminifera, Nature Geoscience, 2, 276-280, doi:10.1038/ngeo460, 2009.

Osburn, C. L., O'Sullivan, D. W., and Boyd, T. J.: Increases in the longwave photobleaching of chromophoric dissolved organic matter in coastal waters, Limnol. Oceanogr., 54, 145-159, 2009.

Ruggaber, R., Dlugi, R. A., and Nakajima, T.: Modelling of radiation quantities and photolysis frequencies in the troposphere, $\mathrm{J}$. Atmos. Chem., 18, 171-210, 1994.

Salonen, K. and Vahatalo, A.: Photochemical mineralization of dissolved organic-matter in Lake Skjervatjern, Environ. International, 20, 307-312, 1994.

Sharpless, C. M.: Lifetimes of Triplet Dissolved Natural Organic Matter (DOM) and the Effect of NaBH4 Reduction on Singlet Oxygen Quantum Yields: Implications for DOM Photophysics, Environ. Sci. Technol., 46, 4466-4473, doi:10.1021/es300217h, 2012.

Shindell, D. T., Faluvegi, G., Koch, D. M., Schmidt, G. A., Unger, N., and Bauer, S. E.: Improved Attribution of Climate Forcing to Emissions, Science, 326, 716-718, doi:10.1126/science.1174760, 2009.

Skalski, M.: Seasonal Estimates of Photochemical Production of Dissolved Inorganic Carbon From Terrestrial Organic Matter in an Altantic Canada Coastal Zone Estuary, MSc, Department of Oceanography, Dalhousie University, Halifax, Nova Scotia, 74 pp., 2006.
Stedmon, C. A. and Markager, S.: The optics of chromophoric dissolved organic matter (CDOM) in the Greenland Sea: An algorithm for differentiation between marine and terrestrially derived organic matter, Limnol. Oceanogr., 46, 2087-2093, 2001.

Stubbins, A., Uher, G., Law, C. S., Mopper, K., Robinson, C., and Upstill-Goddard, R. C.: Open-ocean carbon monoxide photoproduction, Deep-Sea Res. Part Ii-Topical Studies in Oceanography, 53, 1695-1705, doi:10.1016/j.dsr2.2006.05.011, 2006.

Stubbins, A., Hubbard, V., Uher, G., Law, C. S., Upstill-Goddard, R. C., Aiken, G. R., and Mopper, K.: Relating carbon monoxide photoproduction to dissolved organic matter functionality, Environ. Sci. Technol., 42, 3271-3276, doi:10.1021/es703014q, 2008.

Stubbins, A., Law, C. S., Uher, G., and Upstill-Goddard, R. C.: Carbon monoxide apparent quantum yields and photoproduction in the Tyne estuary, Biogeosciences, 8, 703-713, doi:10.5194/bg-8703-2011, 2011.

Swan, C. M., Nelson, N. B., Siegel, D. A., and Kostadinov, T. S.: The effect of surface irradiance on the absorption spectrum of chromophoric dissolved organic matter in the global ocean, Deep-Sea Res. Part I-Oceanogr. Res. Pap., 63, 52-64, doi:10.1016/j.dsr.2012.01.008, 2012.

Tolli, J. D. and Taylor, C. D.: Biological CO oxidation in the Sargasso Sea and in Vineyard Sound, Massachusetts, Limnol. Oceanogr., 50, 1205-1212, 2005.

Tolli, J. D., Sievert, S. M., and Taylor, C. D.: Unexpected diversity of bacteria capable of carbon monoxide oxidation in a coastal marine environment, and contribution of the Roseobacterassociated clade to total CO oxidation, Appl. Environ. Microbiology, 72, 1966-1973, doi:10.1128/aem.72.3.1966-1973.2006, 2006.

Valentine, R. L. and Zepp, R. G.: FORMATION OF CARBONMONOXIDE FROM THE PHOTODEGRADATION OF TERRESTRIAL DISSOLVED ORGANIC-CARBON IN NATURAL-WATERS, Environ. Sci. Technol., 27, 409-412, 1993.

Wang, W., Johnson, C. G., Takeda, K., and Zafiriou, O. C.: Measuring the Photochemical Production of Carbon Dioxide from Marine Dissolved Organic Matter by Pool Isotope Exchange, Environ. Sci. Technol., 43, 8604-8609, doi:10.1021/es901543e, 2009.

Wang, Z. A., Cai, W. J., Wang, Y. C., and Ji, H. W.: The southeastern continental shelf of the United States as an atmospheric $\mathrm{CO} 2$ source and an exporter of inorganic carbon to the ocean, Cont. Shelf Res., 25, 1917-1941, doi:10.1016/j.csr.2005.04.004, 2005.

Weishaar, J. L., Aiken, G. R., Bergamaschi, B. A., Fram, M. S., Fujii, R., and Mopper, K.: Evaluation of specific ultraviolet absorbance as an indicator of the chemical composition and reactivity of dissolved organic carbon, Environ. Sci. Technol., 37, 47024708, doi:10.1021/es030360x, 2003.

Wetzel, R. G., Hatcher, P. G., and Bianchi, T. S.: Natural photolysis by ultraviolet irradiance of recalcitrant dissolved organic matter to simple substrates for rapid bacterial metabolism, Limnol. Oceanogr., 40, 1369-1380, 1995.

White, E. M., Vaughan, P. P., and Zepp, R. G.: Role of the photoFenton reaction in the production of hydroxyl radicals and photobleaching of colored dissolved organic matter in a coastal river of the southeastern United States, Aquatic Sciences, 65, 402-414, doi:10.1007/s00027-003-0675-4, 2003. 
White, E. M., Kieber, D. J., Sherrard, J., Miller, W. L., and Mopper, K.: Carbon dioxide and carbon monoxide photoproduction quantum yields in the Delaware Estuary, Marine Chemistry, 118, 11-21, doi:10.1016/j.marchem.2009.10.001, 2010.

Xie, H. X. and Zafiriou, O. C.: Evidence for significant photochemical production of carbon monoxide by particles in coastal and oligotrophic marine waters, Geophys. Res. Lett., 36, L23606, doi:10.1029/2009g1041158, 2009.

Xie, H. X., Andrews, S. S., Martin, W. R., Miller, J., Ziolkowski, L., Taylor, C. D., and Zafiriou, O. C.: Validated methods for sampling monoxide and headspace analysis of carbon in seawater, Marine Chem., 77, 93-108, 2002.

Xie, H. X., Zafiriou, O. C., Cai, W. J., Zepp, R. G., and Wang, Y. C.: Photooxidation and its effects on the carboxyl content of dissolved organic matter in two coastal rivers in the Southeastern United States, Environ. Sci. Technol., 38, 4113-4119, doi:10.1021/es035407t, 2004.

Xie, H. X., Belanger, S., Demers, S., Vincent, W. F., and Papakyriakou, T. N.: Photobiogeochemical cycling of carbon monoxide in the southeastern Beaufort Sea in spring and autumn, Limnol. Oceanogr., 54, 234-249, 2009.
Zafiriou, O. C., Andrews, S. S., and Wang, W.: Concordant estimates of oceanic carbon monoxide source and sink processes in the Pacific yield a balanced global "bluewater" CO budget, Global Biogeochem. Cycles, 17, 1015, doi:10.1029/2001gb001638, 2003.

Zafiriou, O. C., Xie, H. X., Nelson, N. B., Najjar, R. G., and Wang, W.: Diel carbon monoxide cycling in the upper Sargasso Sea near Bermuda at the onset of spring and in midsummer, Limnol. Oceanogr., 53, 835-850, 2008.

Zhang, Y., Xie, H. X., and Chen, G. H.: Factors affecting the efficiency of carbon monoxide photoproduction in the St. Lawrence estuarine system (Canada), Environ. Sci. Technol., 40, 77717777, doi:10.1021/es0615268, 2006.

Zika, R. G., Saltzman, E. S., and Cooper, W. J.: Hydrogen-peroxide concentrations in the Peru upwelling area, Marine Chemistry, 17, 265-275, 1985.

Ziolkowski, L. A. and Miller, W. L.: Variability of the apparent quantum efficiency of CO photoproduction in the Gulf of Maine and Northwest Atlantic, Marine Chemistry, 105, 258-270, doi:10.1016/j.marchem.2007.02.004, 2007. 